Provided for non-commercial research and education use. Not for reproduction, distribution or commercial use.

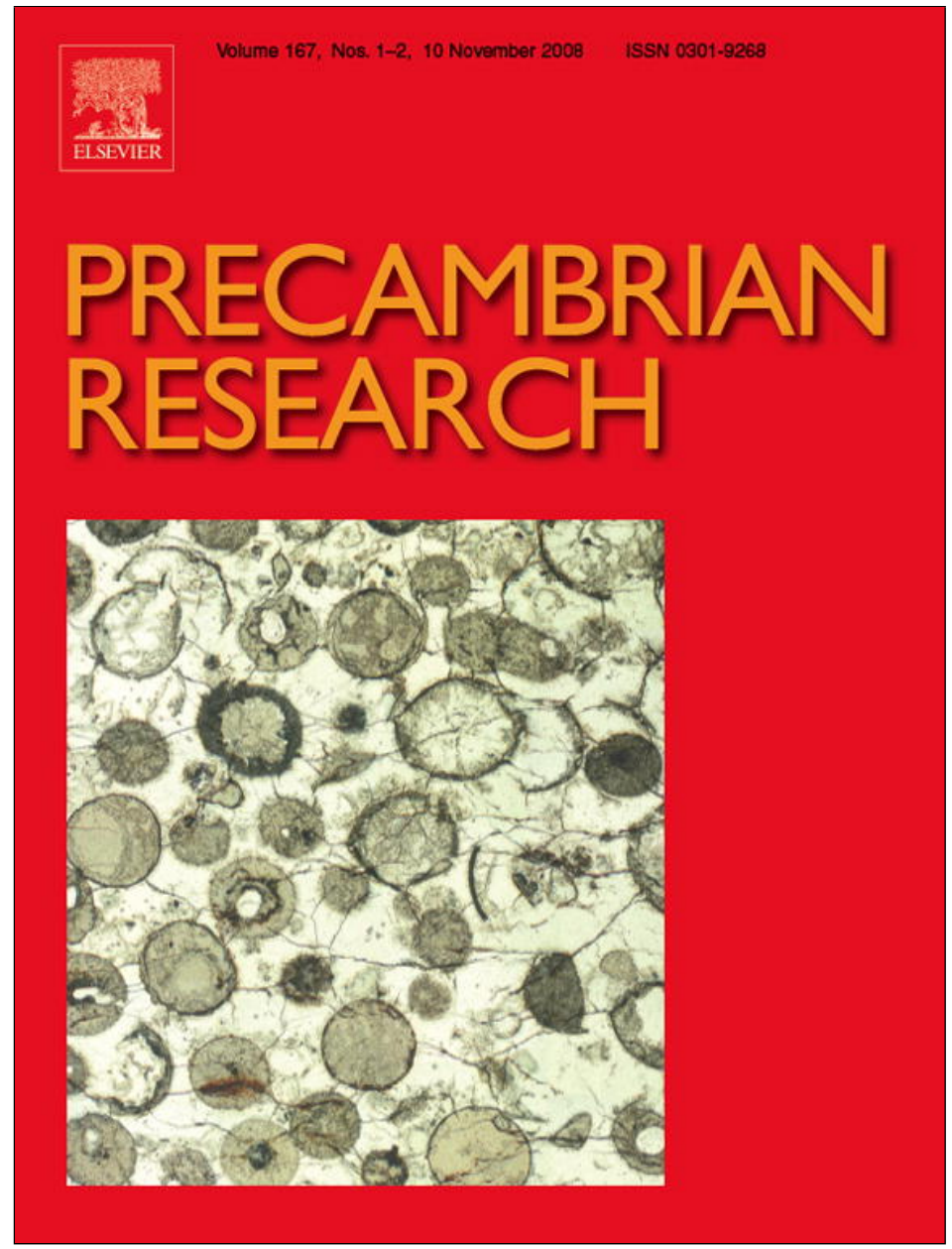

This article appeared in a journal published by Elsevier. The attached copy is furnished to the author for internal non-commercial research and education use, including for instruction at the authors institution and sharing with colleagues.

Other uses, including reproduction and distribution, or selling or licensing copies, or posting to personal, institutional or third party websites are prohibited.

In most cases authors are permitted to post their version of the article (e.g. in Word or Tex form) to their personal website or institutional repository. Authors requiring further information regarding Elsevier's archiving and manuscript policies are encouraged to visit:

http://www.elsevier.com/copyright 
Review

\title{
The Ediacaran microbiota and the survival of Snowball Earth conditions
}

\author{
Małgorzata Moczydłowska* \\ Uppsala University, Department of Earth Sciences, Palaeobiology, Villavägen 16, SE 75236 Uppsala, Sweden
}

\section{A R T I C L E I N F O}

\section{Article history:}

Received 6 December 2007

Received in revised form 7 May 2008

Accepted 6 June 2008

\section{Keywords:}

Acritarcha

Cyanobacteria

Ediacaran

Snowball Earth

Slushball Earth

\begin{abstract}
A B S T R A C T
Recently recovered assemblage of late Ediacaran cyanobacteria, phytoplankton and some microfossils of uncertain origin from the subsurface Włodawa Formation on the Lublin Slope in Poland, allowed to extend their stratigraphic ranges and provided a new evidence that more species survived the Cryogenian Period. Numerous other species of unicellular eukaryotes (informally called acritarchs) and prokaryotes (also coenobial and colonial) have been documented in recent years to lived-over to the Ediacaran, enlarging the global list of biota surviving the Neoproterozoic icehouse intervals. This compelling record revives the issue how marine biota could coup with the catastrophic consequences imposed by the global glaciations and/or to what extent the environmental and climatic change reduced the life habitats. For this purpose, the metabolic processes, modes of life and ecologic habitats of the biota are inferred and analyzed.

The reviewed biota are autotrophic and aerobic: benthic cyanobacteria, which were solitary and largely colonial, living in functionally complex communities of mat-builders, and planktic and/or facultative benthic eukaryotes, which reproduced also sexually and some had advanced life cycle with alternating vegetative and reproductive generations. The environmental requirements of these microorganisms are well-oxygenated open marine waters in the photic zone, and permanent seafloor substrate for benthic and periodic access to bottom sediment for some planktic species with sexual reproduction to rest the cyst. Such natural habitats must have been preserved throughout the Cryogenian Period, and in a substantial extent (environmental "critical mass") to sustain viable populations in the lineages that are represented by surviving species.

Modern analogues of extraordinary adaptations of diverse biota to extreme conditions have their limitations when applied to the Cryogenian Period. Modern extreme environments (like those in Antarctica) with highly specialized organisms are maintained over relatively short time intervals (thousands of years) and may occasionally/periodically be in contact with the outside world to replenish their genetic stock. This is in a sharp contrast to the millions of years of environmental and genetic isolation invoked for the Cryogenian. The global fossil record, enlarged by recent new findings, is briefly reviewed to understand the impact of the Cryogenian glaciations on biodiversity and the rate of survival of microbiota.

The Snowball Earth Hypothesis and its modified versions are discussed in pursuit of an environmentally plausible Earth System model consistent with the survival of biota. The radical version of the Snowball Earth Hypothesis is ruled out. An Earth System model with open marine water, ice-free shelf (at least seasonally) and access to the sea floor is obligatory for the Cryogenian in order to satisfy the living requirements of the biota that survived the period. The palaeobiological findings are entirely consistent with sedimentological findings that require open marine water and well-functioning hydrologic cycle. The Slushball Earth model accommodates more adequately these requirements.
\end{abstract}

(c) 2008 Elsevier B.V. All rights reserved.

\section{Contents}

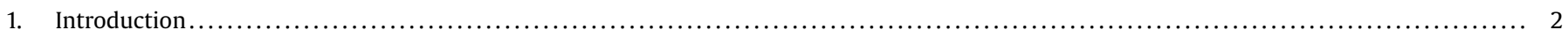

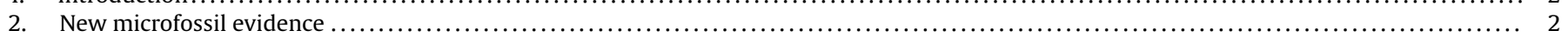

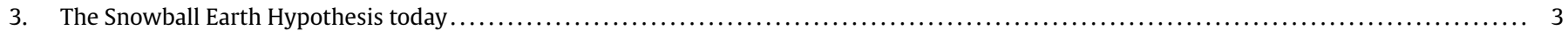

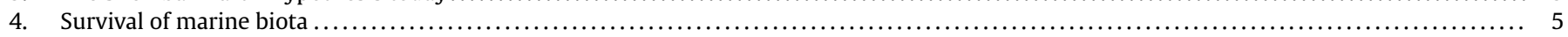

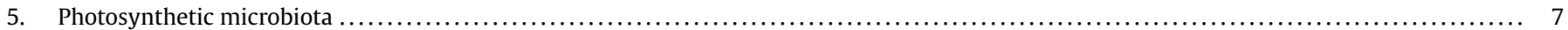

\footnotetext{
* Tel.: +461847127 43; fax: +46184712591

E-mail address: malgo.vidal@pal.uu.se.
} 


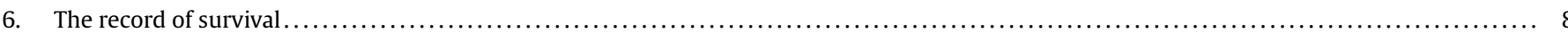

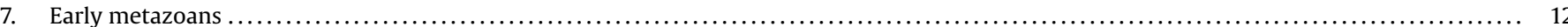

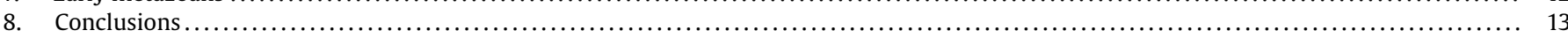

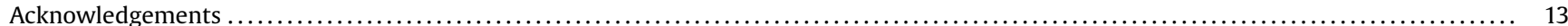

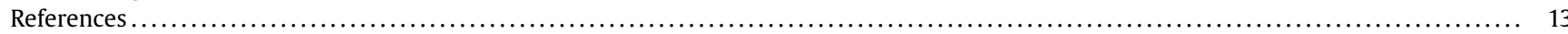

\section{Introduction}

Marine phytoplankton, described under the name Acritarcha and representing predominantly eukaryotic green algae and perhaps cyanobacteria or fungi, and prokaryotic benthic cyanobacteria evolved steadily during the Meso- and early Neoproterozoic, declined during the Cryogenian glaciations and rapidly radiated in the Ediacaran (Sepkoski and Schopf, 1992; Knoll, 1996; Vidal and Moczydłowska, 1997; Grey, 2005; Butterfield, 2005a; Sergeev, 2006; Knoll et al., 2006; Fig. 1). The speciation and extinction events occurred during a time when the Earth experienced major global environmental and climatic changes such as the fragmentation of the Rodinia supercontinent, the final assembly of the Gondwana supercontinent, the Snowball Earth glaciations, oceanic anoxic event and subsequent oxygenation and mixing of the ocean (Powell et al., 1993; Powell and Pisarevsky, 2002; Hoffman et al., 1998; Canfield, 1998; Fike et al., 2006).

The records of benthic filamentous and coccoid cyanobacteria are fragmentary and stratigraphically discontinuous in Neoproterozoic strata. However, occurrences of certain morphologically diagnostic taxa, presumably of the same or close biological affinities, pre- and post-date the Neoproterozoic glaciations. Similarly, some phytoplanktic species survived these long-lasting ecological disturbances, proving that both opportunistic and versatile prokaryotes and more advanced eukaryotes (mostly protoctists) persisted throughout the critical time interval of severe, possibly global glaciations imposed by the Snowball Earth conditions, although diminished in diversity.

Despite the enormous ability of life to adapt to extreme conditions, as known from the modern and perhaps even more profoundly in the past, basic requirements exist to sustain viable populations and genetic stock and to preserve the evolutionary continuum in lineages, particularly in eukaryotic clades with sexual reproduction. For algal phytoplankton, such requirements include a marine environment with open water in the photic zone and access to the sediment to support sexual reproduction with cyst formation. Such phytoplankton, diagnosed by the presence of pylome and/or excystment opening and sporopollenin-like cell wall, evolved well before the Cryogenian glaciations, survived the Snowball Earth conditions although in a limited number of taxa, diversified rapidly and became common in the Ediacaran and then early Cambrian periods (Vidal and Ford, 1985; Jankauskas et al., 1989; Moczydłowska, 1991, 2005; Vidal, 1994; Knoll, 1994, 1996; Grey, 2005; Knoll et al., 2006; Fig. 1). Benthic communities of bacterial mat dwellers, which blanketed the shallow marine sea-beds, naturally needed permanent settlement on sediment substrate and similar aquatic and oxic conditions. They were probable the most common organisms at the time, as seen by their abundance in fossil record, and contributed to rock formation as organic matrix in bacterial moulds, stromatolites, organic-rich shales and laminated carbonates, also occurring in the interglacial intervals (Vidal, 1981; Knoll, 1982; Grey and Corkeron, 1998; Gehling, 1999; Olcott et al., 2005). A model of the Earth System during postulated global glaciations should be compatible with the conditions necessary for sustaining viable populations of surviving taxa.

A newly described association of cyanobacterial, phytoplanktic and some of uncertain origin microfossils from the termi- nal Ediacaran in Poland clearly indicates that more species existed continuously through the times of Cryogenian glaciations (Moczydłowska, 2008). The microfossils derive from the Włodawa Formation in the Łopiennik IG-1 borehole on the Lublin Slope of the East European Platform (EEP). The Ediacaran succession of this borehole and the region is richly fossiliferous additionally with vendotaenids, trace fossils and soft-bodied metazoans (Moczydłowska, 1991; Paczesna et al., 2008).

The global fossil record of surviving microbiota, enlarged by the species documented on the Lublin Slope, is reviewed from the point of view of metabolic processes of the biota and their natural habitats as pre-requisites to evaluate a plausible model of the Earth System during the Cryogenian Period and to test the Snowball Earth Hypothesis.

\section{New microfossil evidence}

A new addition to the Ediacaran records is the microbial association from the Włodawa Formation on the Lublin Slope, which is well-dated biostratigraphically (Moczydłowska, 1991; Paczesna et al., 2008) and may be estimated to ca. $545 \mathrm{Ma}$ (Moczydłowska, 2008; Fig. 1). This age is constrained by the isotopic age of the base of the Cambrian System at $542 \mathrm{Ma}$ (Gradstein et al., 2004), which is recognized some 70-80 $\mathrm{m}$ above the studied record in a sedimentologically continuous succession in the Łopiennik IG-1 borehole, and the maximum age of the late Ediacaran succession in this region post-dating $551 \pm 4 \mathrm{Ma}$ (Compston et al., 1995; Moczydłowska, 2008). The latter isotopic dating is on the tuff layer at the top of the volcanogenic Sławatycze Formation in the Kaplonosy IG-1 borehole by U-Pb on zircon (Compston et al., 1995). The Kaplonosy IG-1 borehole is closely located (only some $30 \mathrm{~km}$ ) to the Łopiennik IG1 borehole and both successions belong to the same tectonic unit and contain the same Sławatycze Formation and the succeeding transgressive sequence, which is similar and correlated bio- and lithostratigraphically and by geophysical logging (Moczydłowska, 2008). The microbial association consists of prokaryotic benthic cyanobacteria and eukaryotic planktic microalgae of the genus Leiosphaeridia, and a morphologically more complex taxon Valkyria, whose affiliation and mode of life is not resolved with certainty, but it is likely a planktic and/or facultative benthic eukaryote (Moczydłowska, 2008; Fig. 2).

Cyanobacterial species in the Lublin association are known from numerous other occurrences and have long, pre-Cryogenian stratigraphic ranges but their new extension to the terminal Ediacaran is pivotal by proving their survival of the Snowball Earth epochs. These are Palaeolyngbya catenata, Tortunema wernadskii, Eoschizothrix composita, Polythrichoides lineatus, Rugosoopsis tenuis, Eoentophysalis belcherensis, Siphonophycus kestron, and Siphonophycus typicum. In natural systematics, the genus Eoentophysalis belongs to a chroococcalean, and all remaining to oscillatoriacean cyanobacteria; they are bacterial-mat-builders, and solitary and colonial dwellers in nearshore and shallow marine habitats (Schopf, 1968; Hofmann, 1976; Golubic and Hofmann, 1976; Seong-Joo and Golubic, 1998). The environmental conditions for their photosynthetic metabolism and life in benthic realm have to be in a photic zone, well-oxygenated marine to brackish waters and in 

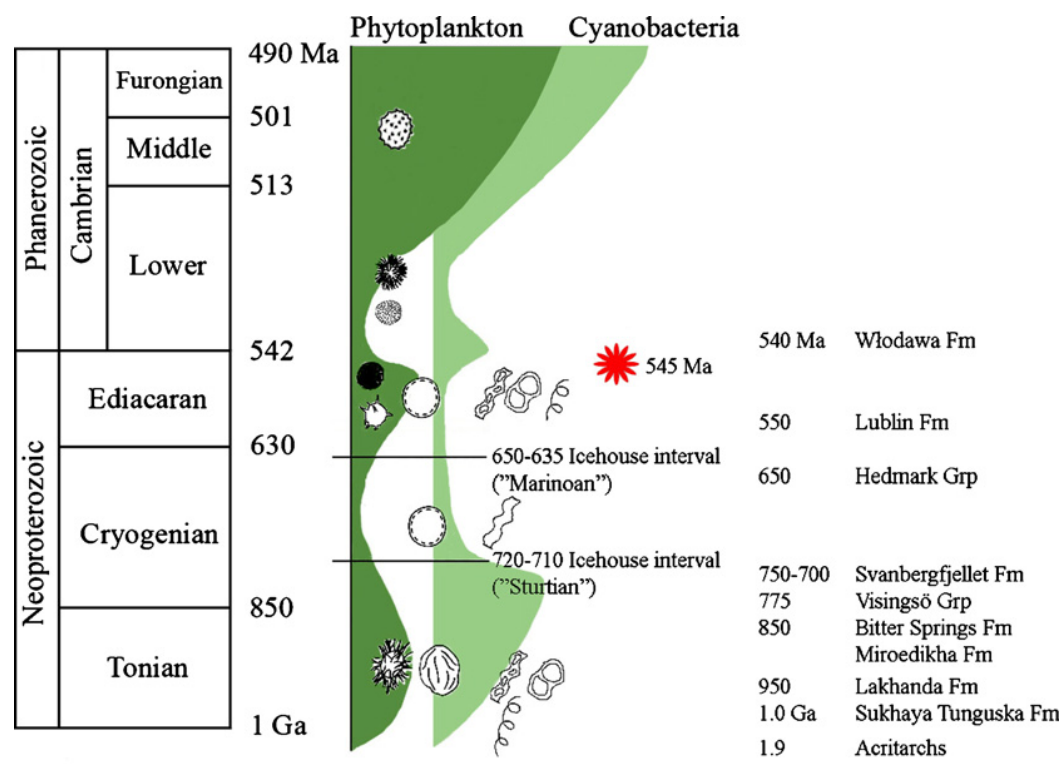

Oritarchs

Fig. 1. Cartoon showing the relative diversity of microbial species (phytoplankton and cyanobacteria) in a global record through the Neoproterozoic and Cambrian times (compiled from Vidal and Moczydłowska, 1997; Grey, 2005; Sergeev, 2006; Veis et al., 2006, and unpublished data). The symbol of red asterisk indicates the chronostratigraphic position of a new record from the Lublin Slope in Poland, estimated to at ca. $545 \mathrm{Ma}$ (Moczydłowska, 2008). The formations consisting of the most diverse microbial assemblages are listed. The geologic time scale is according to Gradstein et al. (2004); the Sturtian icehouse interval is estimated at ca. 720-710 Ma, and the Marinoan icehouse interval at ca. 650-635 Ma (Bowring and Condon, 2006; Knoll et al., 2006; Halverson, 2006). Vertical scale is not in proportion. The total number of phytoplankton species at the end of Cambrian is approximately 400 (unpublished database).

temperature above freezing point (except for short-lasting nocturnal/seasonal periods).

Single-celled leiosphaerids are abundant but taxonomically monotonous, and only two species are distinguished in this association, Leiosphaeridia crassa and Leiosphaeridia minutissima, because of limited phenotypic features. The leiosphaerid vesicle diameter ranging from 10 to several hundred micrometres, sporopollenin-like polymers constructing cell wall, and ubiquitous facies distribution are accepted as indicating eukaryotic microorganisms with planktic mode of life (Tappan, 1980; Moczydłowska, 1991; Martin, 1993; Schopf, 1999; Javaux et al., 2003; Traverse, 2007). The spheroid vesicles may represent both vegetative cells and/or dormant cysts, evidenced in some specimens by the excystment opening, as in modern microalgae. The objective evidence to infer the biological affinity and systematic position of some leiosphaerids is revealed by the trilaminar sheath structure of the cell wall, which is diagnostic for certain clades. Based on such studies and by comparing large populations of leiosphaerids, the species recorded in the Lublin association are recognized as planktic green algae from the Class Chlorophyceae (Talyzina and Moczydłowska, 2000; Arouri et al., 2000; Javaux et al., 2004; Moczydłowska, 2008). The natural habitat, which they have occupied, was a marine, welloxygenated basin in a photic zone, with an access to the sediment substrate for periodic resting/reproductive stage in their life cycle.

Another eukaryote in the association, Valkyria borealis, probably also required more specific conditions for its life, accepting that it was a multicellular organism with predetermined functions (Butterfield et al., 1994), and similar to those of leiosphaerids.

The occurrence of the species from the Lublin association in the uppermost Ediacaran strata is the proof of their survival through several glacial intervals (global and regional) in the Cryogenian Period (Sturtian and Marinoan) and the Ediacaran Period (Gaskiers/Hankalchough).
More numerous species of eukaryotic protoctists and prokaryotes have been recently recorded to lived-over from the pre-glacial intervals to the Ediacaran Period, urging to re-assess the impact of the glaciations on environments and biota and, in reverse, the severity of the Snowball Earth conditions.

\section{The Snowball Earth Hypothesis today}

The roots of the Snowball Earth Hypothesis come out from the idea of a global glaciation of Harland (1964, 2007; see Fairchild and Kennedy, 2007), observing the Neoproterozoic glacial deposits near the palaeo-equator. Kirschvink (1992), who actually coined the name the Snowball Earth, later analyzed the palaeomagnetic and sedimentological evidence suggesting that equatorial glaciers descended to sea level and led to ocean anoxia and deposition of iron-oxide formations.

The Snowball Earth Hypothesis formulated by Hoffman et al. (1998) and Hoffman and Schrag (2002) explains the negative carbon isotope anomalies in carbonate rocks associated with Neoproterozoic glacial deposits in terms of radical climate and environmental change in a scenario of a totally frozen globe for millions of years, with the consequence that biological productivity in the surface ocean collapsed. The Earth's frozen stage conditions ended abruptly because of the slow build up of carbon dioxide from subaerial volcanic outgassing leading to an extreme greenhouse effect and precipitation of cap carbonates worldwide. The global distribution of glacial deposits, including equatorial regions during at least two Neoproterozoic glacial episodes, and the occurrence of banded iron formations suggested that the sea ice covered the ocean, which became anoxic. The hypothesis proposed the presence of continental and shelf ground ice sheets in low latitudes, and disruption of oceanic circulation. In such a hard version of the hypothesis, the only refugia for bacteria and simple eukaryotes could be in melt- 

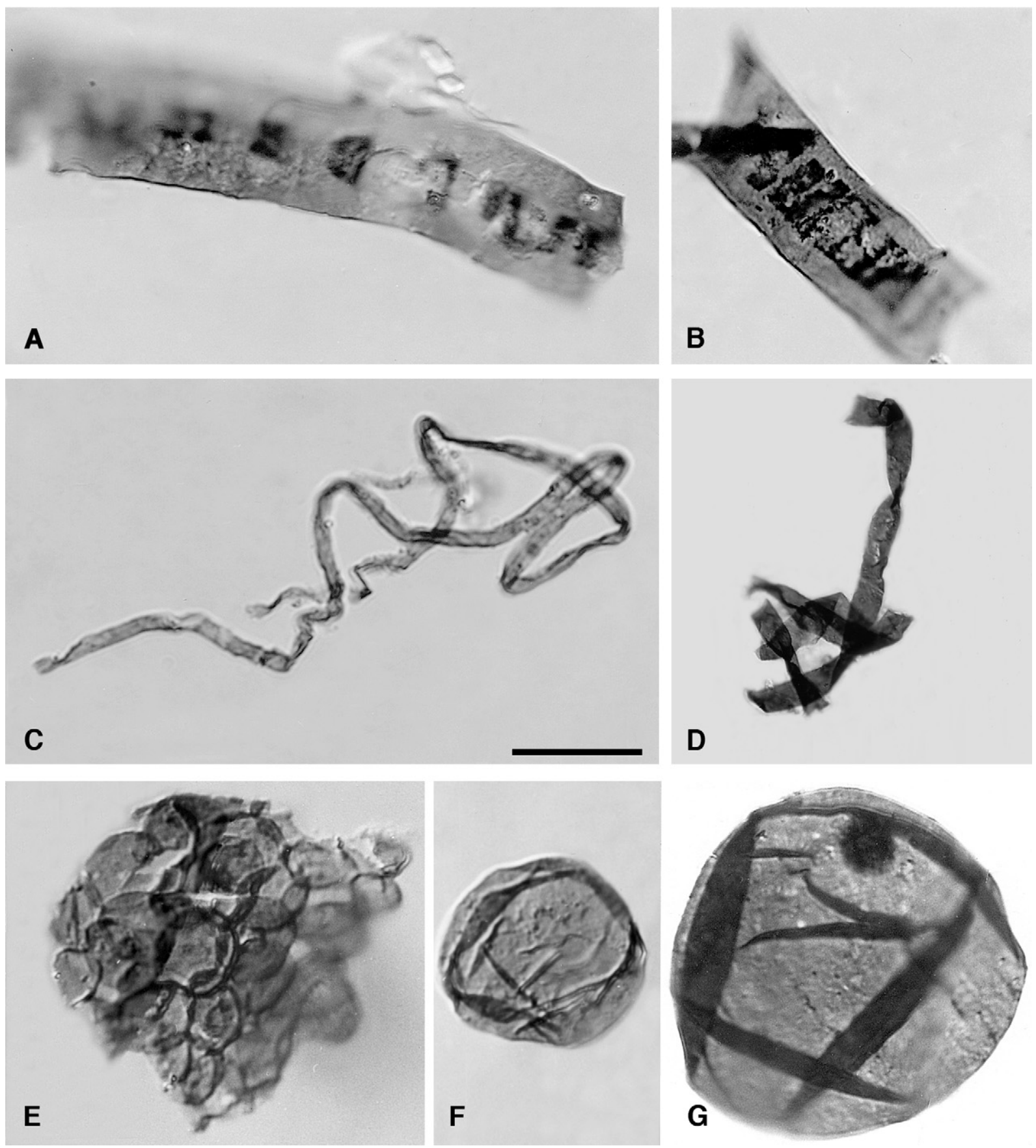

Fig. 2. Representative microfossils with the longest stratigraphic ranges, spanning Mesoproterozoic to Ediacaran. (A and B) Palaeolyngbya catenata Hermann, 1974. Trichomes with cells enveloped by sheaths. (A) Specimen ME-Pl-05/1. K/47/2. (B) Specimen ME-Pl-05/1.M/50. (C) Siphonophycus typicum (Hermann, 1974) Butterfield, 1994. Empty sheath. Specimen ME-Pl-05/3.Y/42/2. (D) Siphonophycus kestron Schopf, 1968. Empty sheath. Specimen ME-Pl-05/1. D/37/1. (A-D) Specimens from Poland, Lublin Slope, Łopiennik IG-1 borehole, Włodawa Formation at a depth of $5385.6 \mathrm{~m} \mathrm{(A,} \mathrm{B,} \mathrm{and} \mathrm{D)} \mathrm{and} 5376.7 \mathrm{~m}$ (C), late Ediacaran. (E) Leiosphaeridia sp. Cluster of minute vesicles. Sample F-81-11. (F) Leiosphaeridia minutissima (Naumova, 1949) Jankauskas, 1989. Sample F-81-11. (G) Leiosphaeridia crassa (Naumova, 1949) Jankauskas, 1989. Sample F-81-14. (E-G) Specimens from Norway, East Finnmark, Varanger Peninsula at Austertana, uppermost Nyborg Formation underlying the Mortensnes Tillite Formation, late Cryogenian. Scale bar in C equals $10 \mu \mathrm{m}$ for $\mathrm{A}$ and $\mathrm{B} ; 80 \mu \mathrm{m}$ for C; $45 \mu \mathrm{m}$ for D; $20 \mu \mathrm{m}$ for E, F, G. All specimens illustrated in this and following figures are photographed in a transmitted light microscope with interference contrast and immersion oil.

water pools and bare ground, ice cracks, open leads or hydrothermal veins. A strong selective pressure on the evolution of life and environmental filter would had been imposed in the Neoproterozoic by these conditions, resulting in genetic "bottleneck" cycles, and perhaps also initiating the metazoan radiation in its aftermath (Hoffman et al., 1998). It was debated furthermore that sea-floor hot springs, rifts in the ice, warm spots of volcanism near the sea surface, and ice leads allowing air in to oxygenate the upper layer of the ocean, could host limited life forms even at the average surface temperature of $-50^{\circ} \mathrm{C}$ and $1 \mathrm{~km}$ thick sea ice (Kerr, 2000).

The Snowball Earth Hypothesis has been repeatedly questioned meanwhile (Kennedy et al., 1998, 2001a,b; Prave, 1999a,b; Condon and Prave, 2000; Allen et al., 2004; Eyles and Januszczak, 2004, 2007; Eyles, 2006, 2008) and its construction doubted with regard to sedimentology, geochemistry, isotopic composition of seawater, terrestrial glaciations, and notable decline of organic productivity 
and conditions evoking near-annihilation of the eukaryotic organisms. Hoffman and Schrag (2002) reinforced their arguments on behalf of the hypothesis and emphasised that the glacial conditions were indeed suitable for the survival of prokaryotes on account of the comparison with modern bacteria living in extreme conditions. They agreed that pre-existing eukaryotic algae, protists (herein referred to as protoctists) and testate amoebae must have survived also and addressed this problem by adding that a variety of refugia could have existed. These could be such as brine channels in new sea ice, open water areas in the tropical ice pack ("polynyas" of Kirschvink, 1992), tidal cracks in the ice-grounding margins, transient meltwater ponds beneath sea ice, and shallow hot springs around volcanic islands. Actually, Kirschvink (1992, pp. 51-52) inferred in his interpretation of the snowball model that "some warm tropical 'puddles' in the sea of ice" would be formed and shifted seasonally along the latitudes and even that solar radiation in the equatorial zone would prevent ice formation. All mentioned habitats (Hoffman and Schrag, 2002) were considered adequate to supply seawater with mineral nutrients due to hydrothermal processes and increased oxygenation to sustain limited organic productivity (Kirschvink et al., 2000; Walter et al., 2000; Hoffman and Schrag, 2000, 2002). However, because of the lack of an active hydrologic cycle and circulation in the ocean under the Snowball Earth conditions, these isolated environmental niches would be available periodically and for short time intervals, otherwise they would be cut off from water exchange and replenishment during prolonged intervals of time. As a consequence of depletion in nutrients and/or oxygen and limitation of the gene pool renewal, the biotic populations would eventually degenerate and ecosystems collapse.

The proposed refugia could be adequate or even conceivable as an environmental filter on the evolution of life and favourable as a "biogeochemical pump" (Hoffman and Schrag, 2002), however, not for a time intervals of one to ten million years as suggested in the Snowball Earth Hypothesis. This is because the hydrologic cycle and global circulation must have been operating to some extent to provide channels for dispersal of microbiota and nutrient supplies (see below).

These extremely unusual conditions for Earth history that are assumed to have existed during the development of a snowballlike world pose the question of how early life might have been able to survive under such environmental stress (Hyde et al., 2000). Computational modelling, simulating the climatic, oceanographic, geochemical and palaeomagnetic factors, has been applied to create the environmental conditions consistent with the Snowball Earth Hypothesis and to test its credibility.

Computer simulations of the Neoproterozoic climate conditions coupled with climate/ice-sheet and general circulation models by Hyde et al. (2000) produced variants of an Earth System with an equatorial belt of open water, later called the "Slushball Earth" hypothesis or "tropical loophole" model. The model elegantly compromised their finding of the presence of open water in the equatorial ocean, even with equatorial glaciation at sea level, and ice-free continental shelves during the near-total glaciation, while being consistent with the anomalous $\partial^{13} \mathrm{C}$ data. The ice-free islands or continental shelves of the model may have provided a refugium in the shallow water substrate for early metazoans which apparently evolved prior to the late Neoproterozoic glaciations, as indicated by the fossil record and molecular clocks (Hofmann et al., 1990; Wray et al., 1996; McNamara, 1996; Fedonkin and Waggoner, 1997; Runnegar, 2000). This model is consistent with a sustained low ocean bioproductivity and is more consistent with fossil records, including the present one (Moczydłowska, 2008). Other models, also incorporating the palaeogeography into parameters of simulations to reproduce past conditions, similarly inferred open ocean areas contradicting the "hard snowball" version of Neoproterozoic glaciations (Chandler and Sohl, 2000; Crowley et al., 2001; Poulsen et al., 2001; Warren et al., 2002; Poulsen, 2003; Peltier et al., 2004; Peltier and Crowley, 2006).

Alternative to the Snowball Earth Hypotheses, supported by available evidence and agreeable although differing in interpretations of the nature of the Cryogenian geological record, are proposed. The "zipper-rift" hypothesis is based on the revised interpretation of certain sediments (diamictites and cap carbonates) accumulated worldwide during the Neoproterozoic and on the explanation of the climate and environmental conditions due to the tectonic processes related to break up of the Rodinia supercontinent (Eyles and Januszczak, 2004; Eyles, 2008). Critical revision concerns the diamictites studied by Hoffman et al. (1998) in the classical Otavi Group in Namibia and other areas in equatorial palaeoposition, which have been taken for granted as glacigenic deposits and proof of severe climatic anomalies. These deposits are seen as the debris flows originating in downslope mass flows in rift basins, whereas cap carbonates are recognized as thin-bedded turbidites (Eyles, 2006, 2008; Eyles and Januszczak, 2007). Accordingly, the erroneous recognition of tillites and cap carbonates attributed to the Sturtian and Marinoan glaciations discredits the evidence of extreme climatic conditions. Other researchers consider, however, the Namibian diamictites as sediments of glacigenic origin (Hoffman et al., 1998; Condon et al., 2002) and there is not a full consensus on the debris flow/turbidite model either (Allen, 2006a,b; Etienne et al., 2007).

The high obliquity hypothesis suggests astronomic causes of the glacial conditions in equatorial zone. The Earth's axial tilt to a much greater degree than today would expose continental masses located in equatorial geographic belt during Neoproterozoic to a limited solar radiation, in fact being in "polar" region, and would allow development of glaciers at low latitudes. As a result of the globe tilting, high seasonality and rapid climate change would occur (Williams, 1975, 1993; Williams et al., 1998). This hypothesis has recently been challenged (Evens, 2006) on the account of new evidence suggesting that the obliquity during the Cryogenian was not different from the one observed today.

The methane hypothesis explains the high variations in geochemical signatures of the carbonates overlying glacial diamictites (cap carbonates) due to a sudden release of buried gas hydrates (methane clathrates) during deglaciation and the ensuing flooding of frozen continental shelves (Kennedy et al., 2001a,b; Jiang et al., 2003).

Refraining from discussing the controversies around the competing hypotheses (see for lively debate at the Snowball Earth Conference in Ascona, 2006 in: Allen, 2006a,b; Shields, 2006; Fairchild and Kennedy, 2007; but also in support, Evens, 2006), I will concentrate on the biosphere and plausible alternatives for its development during the crucial time. The micropalaeontological evidence alone indicates that several clades of microbiota and certain evolutionary lineages of prokaryotes and eukaryotes survived the Neoproterozoic glaciations well. This compelling record deriving from fossils proves a continuity of the process of primary production by photosynthesis in the marine realm and on a persistent occurrence of the environments necessary to sustain the biota.

\section{Survival of marine biota}

The debate on the issue how life could survive the global glacial epochs was polarized from the beginning and split between factions. The hard version of the hypothesis, claiming almost total extinction of photosynthetic organisms because of ice cover blocking sun light and an anoxic ocean (Hoffman et al., 1998; Hoffman and Schrag, 2002), found minor support (Runnegar, 2000; Vincent 
and Howard-Williams, 2000; Xiao, 2004). The palaeobiological data and interpretations opposing such a doom's day for life are conclusive and growing persistently (Grey et al., 2003; Corsetti et al., 2003, 2006; Moczydłowska, 2004, 2006; Grey, 2005; Olcott et al., 2005; Sergeev, 2006; Veis et al., 2006; Moczydłowska, 2008). They are in concert with the climate models inferring the presence of open water basins (by Hyde et al., 2000, and similar) or thin sea ice in the equatorial zone (blue ice cover; Pollard and Kasting, 2005) during the Cryogenian.

Runnegar (2000) analyzed the possible effects on the biosphere imposed by the Neoproterozoic glaciations from the point of view of early animal evolution within the Snowball Earth model of Hyde et al. (2000). Three effects, a snowball bottleneck, a blue-water (pelagic) refugium, and a uniformitarian outcome, could determine the survival of the biosphere. The extreme first option, under the conditions of prolonged frozen ocean surface, anoxia in the abyss and almost complete cessation of photosynthesis (conformed with a hard version of the hypothesis) would result in a mass extinction with only a few eukaryotic lineages surviving in geothermal oases on the continents. The survivors would be predominantly terrestrial in origin (Runnegar, 2000). This could not be seen in the terrestrial fossil record (missing) but is seen in the persistent marine microbial taxa, which range from the Cryogenian to late Ediacaran (Fig. 3) and which were not extinguished by environmental stress. These taxa survived the "snowball" bottleneck but, as argued here, this bottleneck was wider because the Earth's conditions were milder. The uniformitarian outcome, inferring as a consequence non or little evidence for a snowball episode in the evolutionary history of marine eukaryotes, is easily dismissed because the extinction of most early Proterozoic marine biota is well documented (Vidal and Knoll, 1982; Schopf and Klein, 1992; Knoll, 1994; Vidal and Moczydłowska, 1997; Grey, 2005; Knoll et al., 2006).

Runnegar (2000) has also postulated the blue-water refugium for early metazoans, which could have been maintained in their "larval mode" by some environmental filter through the glacial intervals. This solution could explain the survival of metazoans although with extraordinary, and perhaps unlikely, adaptations to continue their evolutionary lineages. However, such a restricted pelagic environment was probably not sufficient enough to maintain viable populations of phytoplankton without an active hydrologic cycle and surface ocean circulation over prolonged time span. It may look like a paradox that planktic autotrophs more than metazoans required access to the marine substrate, at least periodically, but it is argued to be valid (see below).

The extreme conditions in polar regions today, like thick landfast sea ice and ice shelves, are known to support a diversity of life forms, comprising surface communities of bacteria, microbial mat cyanobacteria, protoctists and metazoans (Vincent and Howard-Williams, 2000). This may widen our views and provide

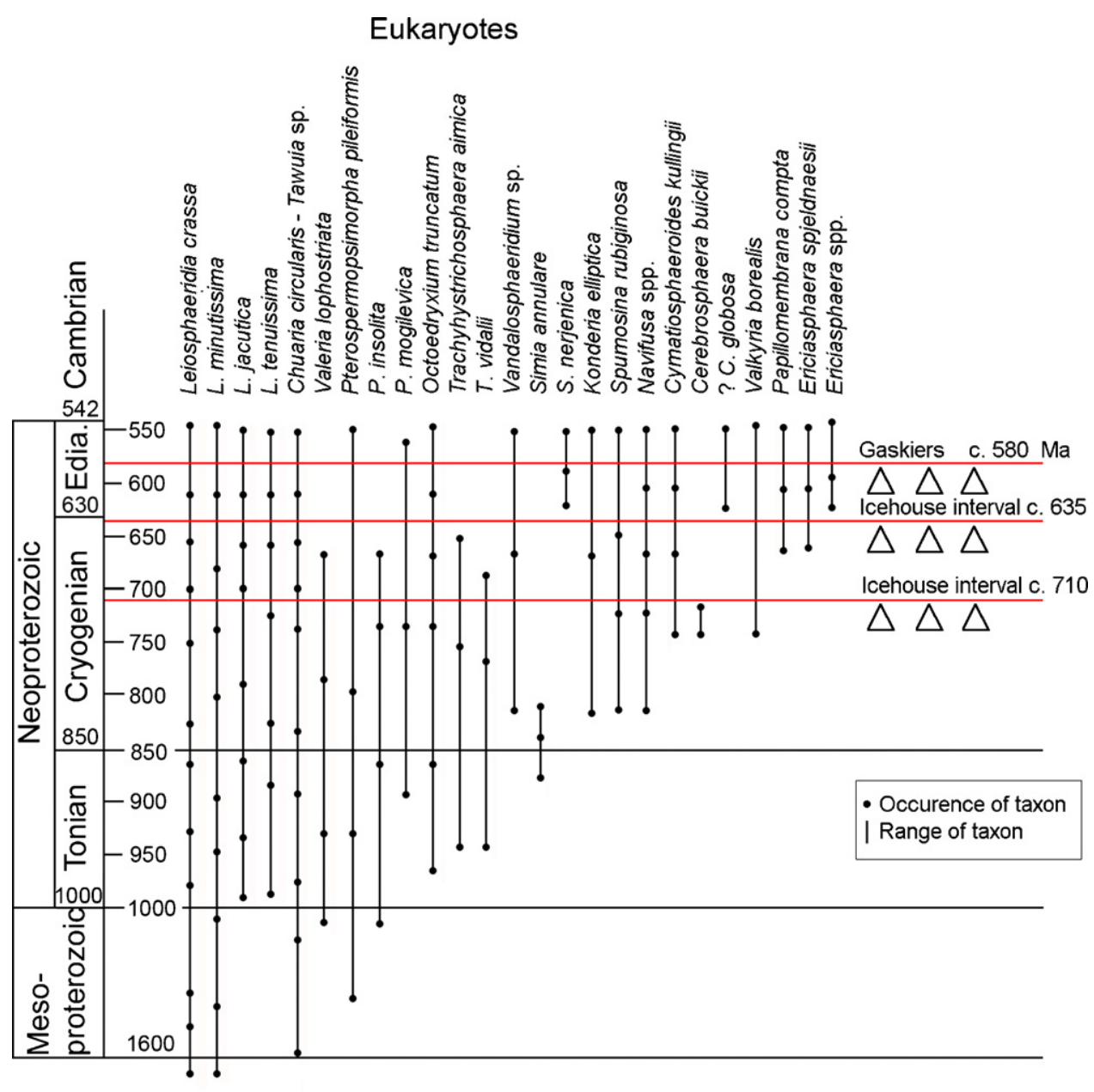

Fig. 3. Range chart of eukaryotic species, which survived the Cryogenian Period, and their approximate ages (various references, see in text). The symbol of triangle marks the chronostratigraphic level of the Sturtian and Marinoan icehouse intervals, and the Gaskiers glaciation, which isotopic ages are according to Halverson (2006). The abbreviation Edia. stands for the Ediacaran Period. 
analogues of how life survived the Snowball Earth conditions of the Cryogenian (Vincent et al., 2000, 2004). The extraordinary temperature tolerance and ability, for example of perennial oscillatorian cyanobacteria, to adapt to freezing conditions and to last inactive for most of the time, then photosynthesize and reproduce in brief periods (days to weeks), could explain the survival strategies. However, the existence of such ice-mat environments and communities in present-day Arctic and Antarctic areas is maintained in relatively short time intervals (hundreds or thousands years perhaps; Kapitsa et al., 1996; Bell et al., 2002, 2007; Wingham et al., 2006). There is also an occasional or periodic exchange of bacterial-protoctistan spores by wind dispersal and by ocean currents with the outer and "normal" world full of life, which according to the Snowball Earth scenario did not pertain. In a time frame of the Cryogenian glacial intervals such environments would be highly ephemeral and unsustained. Therefore, the application of modern analogues has its limitations.

The examples of modern extreme environments, like those of the Antarctic subglacial lakes and ice streams, have been suggested as analogues for refugia in which life could survive adverse conditions during the Cryogenian Period. The comparison to such modern systems, e.g. the best studied and the largest Lake Vostok, was based on the assumption that they are stagnant, without active hydrology or drainage (Kapitsa et al., 1996; Bell et al., 2002), and closed for several million years (McKay et al., 2003). The new observations and assessments radically verified, however, these early assumptions and showed instability of subglacial lake systems and rapid discharges, floods, periodic flushing and drainage of subglacial basins and transfer of water to the ocean (Wingham et al., 2006; Lewis et al., 2006; Bell et al., 2007). The rapid discharges are periodic and a normal mode of water transfer, observed to take between a few days to few months, and in one of smaller lakes with a recurrence every 36 years; moreover, the residence time of water in subglacial lakes is short in comparison with the age of the basal ice and contrasting with previous estimations of millions years (Wingham et al., 2006).

The microbe relocation occurs through the water transfer between subglacial lakes and into the ocean, affecting microbial diversity and causing circulation in the entire flood drainage system (Wingham et al., 2006). Thus, the hydrologic system is open, although with a slower circulation when not in direct contact with atmosphere, and biosphere (or cryosphere) is neither isolated in modern glacial environments, therefore such environments do not support analogue refugia sites during the Cryogenian Period inferred to be sealed for millions years.

\section{Photosynthetic microbiota}

The modern microbial communities show strong environmental preference along lineages because of the habitat preference of microorganisms through time based on their functional capacities. This hypothesis is quantitatively well supported by now by the metagenomics data (von Mering et al., 2007), but it has been formulated decades ago by Bass-Becking and Beyerinck (Martiny et al., 2006). There is a remarkable stability of microbial lineages associated with a certain habitats for extended time periods and an adaptation to a new environment is a rare event. The bacterial clades display a long-lasting habitat preferences (von Mering et al., 2007). It is consistently observed back in time when ancient environmental data is combined with associated taxa and entire assemblages of cyanobacteria and phytoplankton (Cloud, 1988; Schopf, 1999; Knoll, 2003). Taken together with the record of microbiota which survived the Cryogenian Period, it is obvious that the habitats must have been preserved over this time, instead of that the microorganisms would have adapted to extreme glacial and very different indeed environments, as it would be needed following the Snowball Earth Hypothesis, and then repopulated again after the conditions returned to normal.

Moreover, microbial lineages neither often change nor specialize their life mode, similarly as they do not change their habitats (von Mering et al., 2007). As for algal plankton (including leiosphaerids recorded here) it is even more vital to have seafloor habitats preserved to maintain their complex reproduction cycle (see below). The climate fluctuations enhance the flow of low-salinity waters on continental shelves and this freshening alters circulation and stratification, and affects the abundance and seasonal cycles of phytoplankton observed today (Greene and Pershing, 2007). The freshening of the marine water enhances stratification and increases phytoplankton production and abundance seasonally (autumn). This would likely have similar effect during the Cryogenian glacial-interglacial epochs, yet the records show only decline of diversity and are so rare, or appropriate successions have not been sufficiently studied, to actually detect phytoplankton response to the glaciations more than surviving.

Phytoplanktic algae (most acritarchs), among other eukaryotic microbiota, achieved their evolutionary grade to reproduce sexually (as all eukaryotes do) and to alternate sexual/vegetative stages in their life cycle certainly prior to the Cryogenian (Tappan, 1980; Vidal and Ford, 1985; Colbath and Grenfell, 1995; Butterfield, 2000; Javaux et al., 2003; Moczydłowska, 2004, 2006; Grey, 2005; Knoll et al., 2006). As such, they could not revert their reproduction to totally asexual for several million years envisaged for the glacial epochs, and once again to a sexual cycle and production of cysts in the Ediacaran (evident also in the Ediacaran acritarchs by the presence of excystment structure; Moczydłowska, 2005; Grey, 2005). Some genera of algal origins (Talyzina and Moczydłowska, 2000; Arouri et al., 2000; Javaux et al., 2004) and reproducing by cysts studied here (Leiosphaeridia) survived the Cryogenian crisis unchanged, as documented by their stratigraphic ranges (Jankauskas et al., 1989; Grey et al., 2003; Grey, 2005; Sergeev, 2006; Veis et al., 2006; Moczydłowska, 2008; Fig. 3).

Development of various modes of life (a result of environmental adaptation) and reproduction cycles (sexual genetic recombination and alternation of generations in eukaryotes and periodic/seasonal mass blooms of vegetative populations in prokaryotes) was the mechanism that increased the ability to survive the extreme environmental stress. Formation of the cyst, the excystment structure (pylome), and alternation of the generations (sexual and vegetative) in the life cycle of acritarchs indicate the development of early strategies to survive ecological crisis and as a competitive advantage in the increasingly complex marine ecosystems (Moczydłowska, 2002). However, to maintain the alternation of generations and to produce a cyst, photosynthesizing plankters must have had an access to the bottom sediment to rest periodically before popping-up into the photic zone as modern algae do. This condition and the evidence of persisting taxa, both of planktic acritarchs (algal phytoplankton, obligate aerobes) and benthic cyanobacteria (obligate and facultative aerobes), proves that marine photosynthesis and bioproductivity in the ocean occurred throughout the Cryogenian Period (Moczydłowska, 2004, 2006, 2008). Consistently, although limited in extent, the marine shelf environments, including seafloor sediments, were free from permanent ice cover at low latitudes, allowing sunlight penetration into some depth of the water column, oxygen exchange with the atmosphere and replenishment of nutrients due to a sustained hydrologic cycle. Active hydrologic cycle to maintain the biosphere alive corroborates the same inferences based on sedimentologic records (Condon et al., 2002; Eyles and Januszczak, 2004, 2007).

Restricted microenvironments, postulated to exist during the Snowball Earth epochs, could sustain only small populations viable 
for a rather short period of time, by comparison with actualistic extreme life habitats (Thomas and Dieckmann, 2002), but not exceeding millions of years. The exchange of water and replenishment of mineral (for autotrophs) and organic (for heterotrophs) nutrients would be impossible without circulation and hydrologic cycle, if not globally than at least in a larger basin. More significantly, dispersal of microbiota (known to be mostly passive plankton at the time) would be cut off and exchange of the gene pool halted. This would inevitably lead to genetic degeneration, ecosystem collapse and extinction. If to accept the interpretation by Butterfield (2005a,b; Knoll et al., 2006) that certain Proterozoic acritarchs were "rather heterotrophic than photosynthetic and benthic rather than planktonic", the demand would be even higher to have available substrate for those biota as well as the need for photosynthesis to supply more food for these additional alleged heterotrophs. Chemoautotrophy alone, as a source of food, could not maintain the eukaryotic complex ecosystem for long.

Thus, the assumption is that photosynthetic microbiota, which are at the base of the trophic web, and their metabolic/ecologic requirements must have been sustained throughout the Cryogenian, not only allowing them to survive but also to support heterotrophs, including protoctists and earliest metazoans. Therefore, adequate and sufficiently robust environments must have been preserved and any Earth System model of this time needs to conform to this requirement.

\section{The record of survival}

In general, the question is how could we estimate the rate of survival and the impact of climatic/environmental change on the biosphere during the Cryogenian on a global scale. The direct evidence is provided by the fossil record of organisms, which survived the glaciations, their well-constrained stratigraphic ranges predating glaciations and extending into the Ediacaran, and recognition of their life habitats, which must have been preserved, even though some biota could adapt to slightly different ecological conditions. The biota is almost entirely microbial and profoundly autotrophic. Early metazoans only come into the picture later and in the form of a very limited fossil record. This is known from published data and previous compilations in databases (Jankauskas et al., 1989; Schopf and Klein, 1992; Knoll, 1994, 1996; Vidal and Moczydłowska, 1997; Knoll et al., 2006), and from new findings in recent years (Grey et al., 2003; Grey, 2005; Corsetti et al., 2003; Sergeev, 2006; Veis et al., 2006; Yin et al., 2007; Willman and Moczydłowska, 2008; Moczydłowska, 2008; Fig. 1). Indirect evidence for the existence of biota and their diversity, although in a broad systematic sense, is also provided by biomarkers (Olcott et al., 2005) and biogenic fractionation of carbon isotopes, which indicates fluctuations in primary productivity and burial of organic carbon but may not be unequivocally interpreted (see discussion by Corsetti et al., 2006).

It is well understood that the Neoproterozoic fossil record is sparse and very unevenly distributed in various chronostratigraphic units, representing rather exceptional windows into evolutionary development and biodiversity. The available records are, however, from a wide array of environments and sufficiently robust to allow recognition of richness of discrete species and higher taxonomic ranks or clades, and evolutionary rates of speciation and extinction through time. The basic metabolic processes (nutrition, respiration and reproduction), modes of life (planktic, benthic), life habitats and ecologic requirements of many extinct organisms are also known by comparison to modern analogues. The most comprehensive documentation and estimation of Proterozoic biodiversity by Schopf and Klein (1992) and subsequent analyses (Knoll, 1994, 1996; Vidal and Moczydłowska, 1997; Knoll et al., 2006) paved the ground for evaluating the biotic survival through the Cryogenian Period. There are obviously some differences in the details of databases and methods of quantifying the fossil record, which are revealed by the total number of accepted species reflecting the researchers' own taxonomic criteria and palaeobiological interpretations (Sepkoski and Schopf, 1992; Vidal, 1994). Regardless of the approach, the common outcome is clear in all compilations. Apparently, a substantial number of microbial species survived the critical period of glaciations as seen by their stratigraphic ranges extending from the early Neoproterozoic into the Ediacaran. These are, in general, cyanobacteria and protoctists, mostly acritarchs of algal origin and other organic-walled organisms of uncertain affinities. The time resolution is too poor and the time intervals binding the records (100-50 Ma), which were used in hitherto produced diversity charts, are too rough to relate accurately the events of radiations and extinctions to particular glacial events. The latter events are either unconstrained in time by precise isotopic ages or relevant age constraints have been forthcoming only recently. These predicaments are irrelevant for proving that certain species and clades survived well the Cryogenian, but prevent us from knowing which glacial episode caused higher levels of extinction of the successive glacial epochs. The relative ages of the species, even in the absence of robust absolute age constraints are sufficient because they overlap the strata containing glacial sediments, and this combined stratigraphic method has been used to construct previous biodiversity curves and is used herein (Fig. 3).

The cumulative number of species recorded in pre-, inter- and post-glacial deposits renders possible estimation of the rate of survival and impact of the Snowball Earth conditions on the biosphere. The total number of around 20 species of protoctists (mostly acritarchs) recorded in the Cryogenian glacial interval (referred previously in general term to as the Varangerian ice age) is consistent in all compilations (Sepkoski and Schopf, 1992; Knoll, 1994; Vidal and Moczydłowska, 1997). The new records of surviving eukaryotic taxa (Grey, 2005; Sergeev, 2006; Veis et al., 2006; Yin et al., 2007; Willman and Moczydłowska, 2008; Moczydłowska, 2008; Fig. 3; see below) should be added, accounting to around 30 species. In all cited analyses, the biodiversity curve fluctuations, showing the changing pattern of speciation-extinction and trends in evolving complexity and dynamics of ecosystems, are consistent although the quantitative estimation of diversity in each time bin may be slightly different. The progressive and steady increase of protoctistan diversity during the early Proterozoic reached the maximum number of species around 35 (Knoll, 1994) or 60 (Vidal and Moczydłowska, 1997). The diversity declined to ca. 30 species during the glacial intervals and again climbed to ca. $60-65$ species in the post-glacial time (Knoll, 1994; Vidal and Moczydłowska, 1997) or over 100 species (Grey, 2005). Even if the number of species is approximate, because of bias from sampling, taphonomy and taxonomy of biota, the observation is valid that the extinctions during the glacial intervals eliminated around $50 \%$ or perhaps up to $65 \%$ of the pre-existing species. There are only two known species that originated during the interglacial time interval (Papillomembrana compta and Ericiasphaera spjeldnaesii; Vidal, 1990; Fig. 3; see below), and they survived into the Ediacaran (Zhang et al., 1998). Remarkably, the percentage of species, which became extinct during the Cryogenian glacial events, is much lower than at the end-Ediacaran mass extinction, when almost all species were eliminated (Vidal and Knoll, 1982; Vidal and Moczydłowska, 1997; Grey, 2005; Knoll et al., 2006).

The additional record of surviving taxa is briefly reviewed here (Figs. 3-6). They are unicellular eukaryotes (or otherwise stated), photosynthetic algae and some of unknown affinities, planktic and/or benthic, and as such having certain environmental pre-requisites, as discussed above. These taxa have distinct morphology (except leiosphaerids) and well-determined ages to 

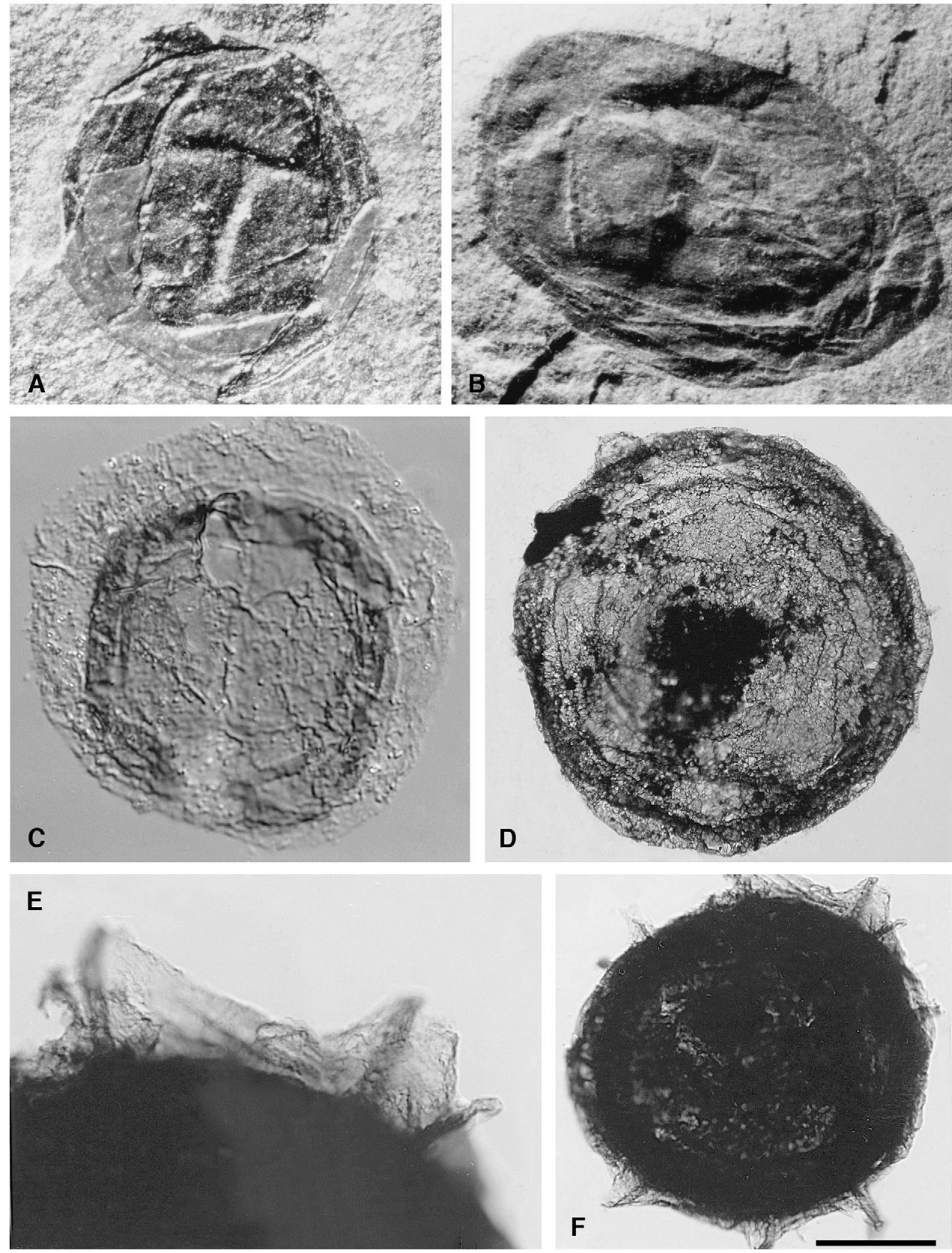

Fig. 4. Long-lived eukaryotic taxa (except Beltanelloides) with distinctive morphology. (A) Chuaria circularis (Walcott, 1899) Vidal and Ford, 1985. Yakutia, Lena-Anabar Depression, Khastakh 930 borehole at a depth of 3108.2-3111.9 m, Khajpakh Formation, late Tonian-early Cryogenian. (B) Beltanelloides sp. Spain, Central Iberia, Rio Huso section at Navafria, Pusa shale, late Ediacaran. (C) Simia annulare (Timofeev, 1969) Mikhailova and Jankauskas, 1989. Yakutia, Lena-Anabar Depression, Khastakh 930 borehole at a depth of 2903.9-2910.0 m, Khajpakh Formation, late Tonian-early Cryogenian. (D) Simia nerjenica Weiss, 1989. Australia, Officer Basin, Giles 1 borehole at a depth of $425.75 \mathrm{~m}$, Tanana Formation, late Ediacaran. (E and F). Trachyhystrichosphaera vidalii Knoll, 1983. Yakutia, Lena-Anabar Depression, Khastakh 930 borehole at a depth of 2903.9-2910.0 m, Khajpakh Formation, late Tonian-early Cryogenian. Scale bar in F equals $300 \mu \mathrm{m}$ for A; $3 \mathrm{~mm}$ for B; $20 \mu \mathrm{m}$ for C; $145 \mu \mathrm{m}$ for D; $30 \mu \mathrm{m}$ for E; $100 \mu \mathrm{m}$ for F. 

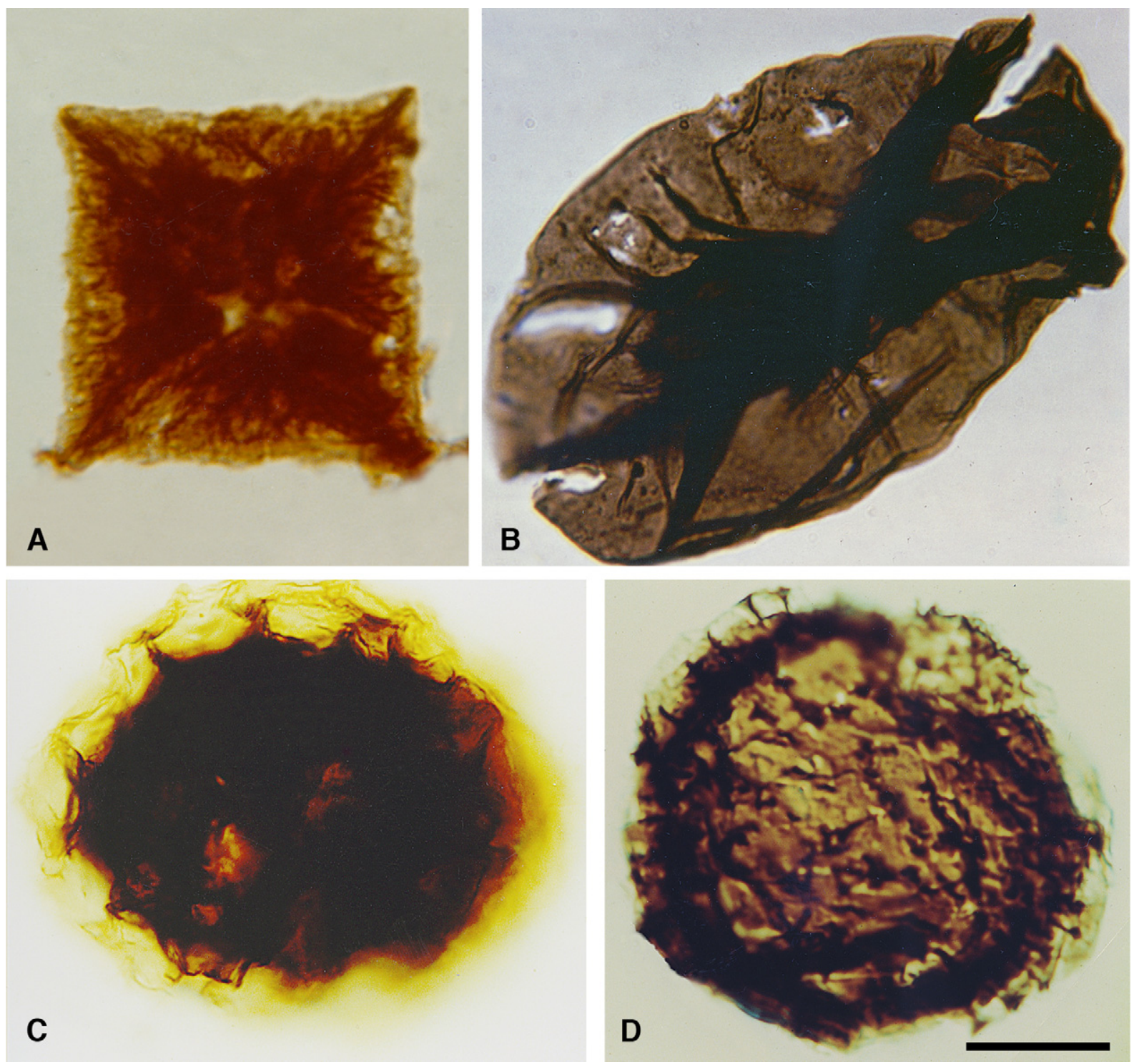

Fig. 5. Eukaryotic genera, which survived the Neoproterozoic icehouse intervals (Sturtian and Marinoan) and the Gaskiers glacial epoch. (A) Octoedryxium truncatum (Rudavskaya, 1973) Vidal, 1976. Sweden, Visingsö Lake at Mullskräden section, upper Visingsö Group, early Cryogenian. (B) Leiosphaeridia jacutica (Timofeev, 1966) Mikhailova and Jankauskas, 1989. Norway, Finnmark, Varanger Peninsula, Vadsö Group, Klubbnes Formation, early Cryogenian. (C) Vandalosphaeridium reticulatum (Vidal, 1976) Vidal, 1981. Sweden, Visingsö Lake at Mullskräden section, upper Visingsö Group, early Cryogenian. (D) Vandalosphaeridium walcottii Vidal and Ford, 1985. U.S.A., Grand Canyon, Chuar Group, Kwagunt Formation, early Cryogenian. Scale bar in D equals $25 \mu \mathrm{m}$ for A; $60 \mu \mathrm{m}$ for B; $20 \mu \mathrm{m}$ for C; $10 \mu \mathrm{m}$ for D.

demonstrate their persistence through the Cryogenian glacial epochs.

The long-living are four leiosphaerid species, which are commonly recognized and have ranges extended to the end of Ediacaran or even to the Cambrian (Grey, 2005; Sergeev, 2006; Veis et al., 2006; Moczydłowska, 2008; Figs. 3, 5B and 6D). The Chuaria-Tawuia pair of macrofossils is often found in assemblages with other carbonaceous compressions such as Beltanelloides sp., (Hofmann and Aitken, 1979; Vidal et al., 1993; Vidal, 1994; Xiao and Dong, 2006; Fig. 4A and B). Chuaria circularis is interpreted to be of an algal origin, planktic prasinophycean or reproductive cyst of a thallophyte (Vidal and Ford, 1985; Vidal et al., 1993), or benthic or having a benthic stage in life cycle (Xiao and Dong, 2006). Tawuia is probable a thallophytic alga (Vidal et al., 1993), benthic and perhaps ontogenetically related to Chuaria (Xiao and Dong, 2006). The first appearance datum (FAD) of $C$. circularis is at ca. $1650 \mathrm{Ma}$ (Sergeev, 2006; Fig. 3) and the species occurs more frequently also as an isolated fossil from ca. $1000 \mathrm{Ma}$ (Vidal et al., 1993). The last appear- ance datum (LAD) of $C$. circularis is within the topmost Doushatuo Formation in China, estimated to ca. $550 \mathrm{Ma}$ (Zhang et al., 1998). It conforms to the occurrence of the species in the Vychegda Formation on the EEP in Arctic Russia (Vendian age; Veis et al., 2006), which is of the late Ediacaran age interpreted here by the correlation with the complex acritarch palynoflora in Australia. The latter is estimated to be younger than ca. $570 \mathrm{Ma}$ (Grey, 2005).

The genus Pterospermopsimorpha originated in Mesoproterozoic; the FAD of Pterospermopsimorpha pileiformis is in the Burzyansk Formation in Southern Urals, bracketed within an interval of 1650-1350 Ma (Sergeev, 2006), and its LAD is in the Vychegda Formation (Vendian age; Veis et al., 2006) of the late Ediacaran age. Two other species, Pterospermopsimorpha insolita and Pterospermopsimorpha mogilevica, originated also in the preCryogenian times; the estimated range of $P$. insolita is $1100-630 \mathrm{Ma}$ (Jankauskas et al., 1989), so it survived only the Sturtian epoch. The FAD of $P$. mogilevica is recorded in the Vadsö Group in Finnmark, Norway, which underlies the Tanafjord Group and both 

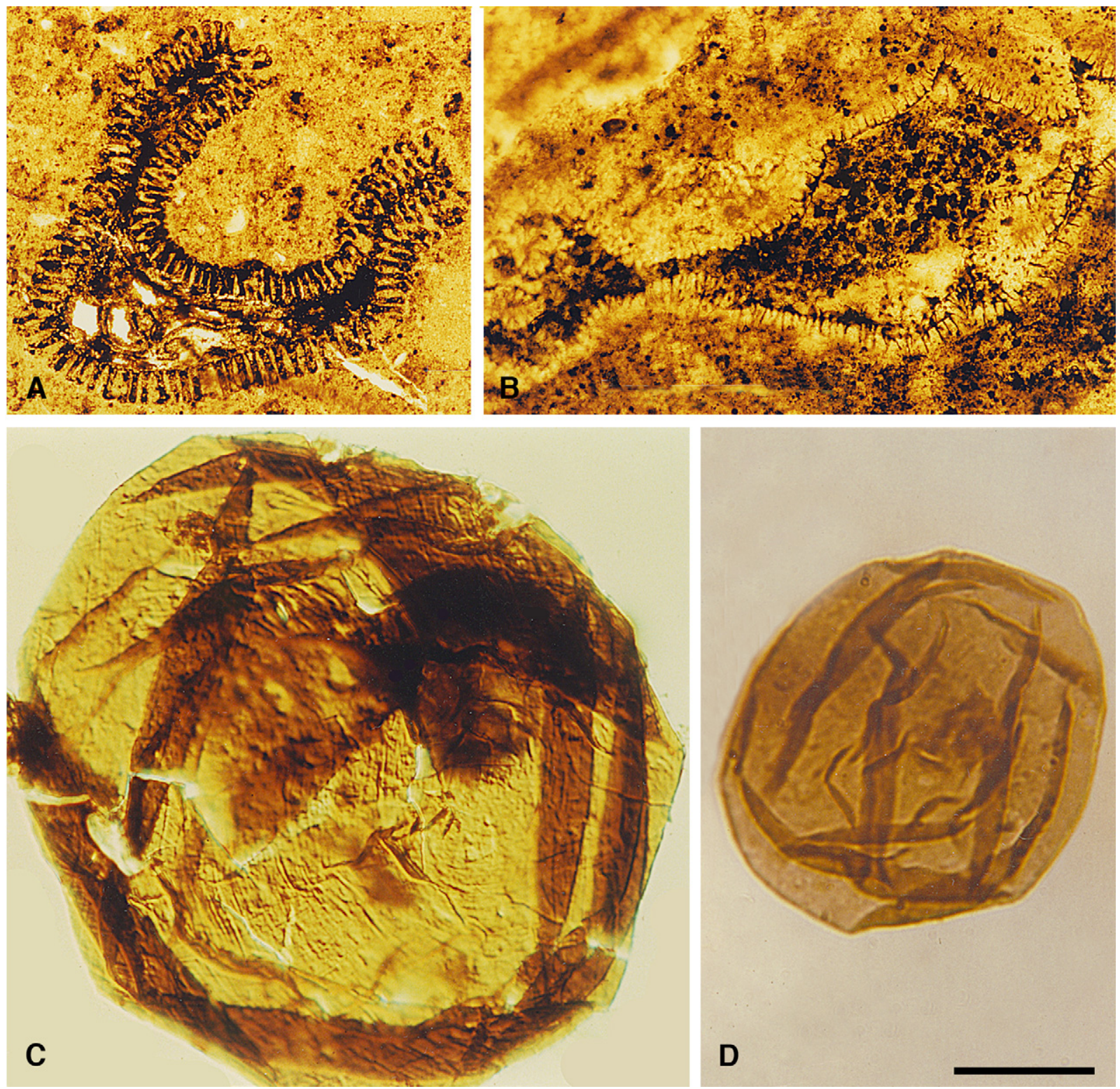

Fig. 6. Eukaryotic species, which survived some of the Neoproterozoic icehouse intervals: Papillomembrana compta and Ericiasphaera spjeldnaesii (Marinoan and Gaskiers), Valeria lophostriata (only Sturtian), whereas Leiosphaeridia jacutica all glacial intervals. (A) Papillomembrana compta (Spjeldnæs, 1963) Vidal, 1990. (B) E. spjeldnaesii Vidal, 1990. (A and B) Norway, Mjøsa Lake area at Hjellund, Hedmark Group, Biskopås Conglomerate, late Cryogenian. (C) Valeria lophostriata (Jankauskas, 1979) Jankauskas, 1982. U.S.A., Grand Canyon, Chuar Group, Kwagunt Formation, early Cryogenian. (D) Leiosphaeridia minutissima (Naumova, 1949) Jankauskas, 1989. Sweden, Visingsö Island, Kumlaby borehole at a depth of $50.8 \mathrm{~m}$, lower Visingsö Group, early Cryogenian. Scale bar in D equals $160 \mu \mathrm{m}$ for A; $50 \mu \mathrm{m}$ for B; $45 \mu \mathrm{m}$ for C; $20 \mu \mathrm{m}$ for D.

are beneath the Varangerian tillites (Smalfjord and Mortensnes; Vidal, 1981), whereas its LAD is in the Ostrozhsk Formation in the Ukraine (Vendian; Timofeev, 1973) of the early Ediacaran age.

Several other species that appeared in the Tonian or early Cryogenian times have been recently recorded in the Ediacaran strata equivalent to the post-Gaskiers interval. These are Octoedryxium truncatum, Vandalosphaeridium spp., Konderia elliptica, Spumosina rubiginosa, Navifusa spp., Cymatiosphaeroides kullingii, and Cymatiosphaeroides sp. (Jankauskas et al., 1989; Grey, 2005; Veis et al., 2006; Yin et al., 2007; Fig. 5A, C and D). A few more, with the same time of origination, became extinct in the Cryogenian interglacial epoch and lived-over only the Sturtian glaciation; these are Valeria lophostriata (Jankauskas et al., 1989), Trachyhystrichosphaera aimica, and Trachyhystrichosphaera vidalii (Knoll et al., 1991; Vidal et al., 1993; Sergeev, 2006; Figs. 4E and F, 6C).
The genus Simia is of an interest although its two discrete species have short and off-lapping ranges, Simia annulare in the late Tonian-early Cryogenian (Vidal et al., 1993), and Simia nerjenica in the Ediacaran (Veis et al., 2006; Willman and Moczydłowska, 2008; Fig. 4C and D). The microbiota, at the genus level, shows a continuous evolutionary lineage through the Neoproterozoic glacial intervals. Comparably, the genus Cerebrosphaera, which FAD is within the Svanbergfjellet Formation underlying the Cryogenian tillites and estimated to an age around 700-750 Ma (Cerebrosphaera buickii; Butterfield et al., 1994), seems to continue its range into the Ediacaran, although recorded by another species (?Cerebrosphaera globosa; Veis et al., 2006). V. borealis appeared also for the first time in the Svanbergfjellet Formation (Butterfield et al., 1994) but it has survived the multiple glaciations to the end of Ediacaran (Moczydłowska, 2008; Fig. 3). 
Two genera, Papillomembrana and Ericiasphaera seem to be the only so far recognized taxa, which originated in the Cryogenian interglacial epoch. The FAD of the monospecific former genus, identified by $P$. compta is in the Biskopås Conglomerate, underlying the Moelv Tillite in the Hedmark Group in southern Norway (Vidal, 1990; Fig. 6A). The Moelv Tillite is older than $612 \pm 18 \mathrm{Ma}$ and considered Cryogenian in age (Marinoan) (Vidal and Moczydłowska, 1995), but it has been recently suggested to be post-Marinoan, or even not glacial in origin (Halverson, 2006). The post-Marinoan age was inferred from the dating of the detrital zircon in the Rendalen Formation underlying the Moelv Formation and calculated to $620 \pm 14 \mathrm{Ma}$ (Bingen et al., 2005). This maximum age for the Moelv Tillite is still in the range of $634 \mathrm{Ma}$, thus not excluding the Marinoan age, giving the reliability and precision of the isotopic measurements and the calculated intervals for the global glaciations, which are far from being agreed. The LAD of $P$. compta is in the upper Doushantuo Formation at ca. $550 \mathrm{Ma}$ (Zhang et al., 1998; Yin et al., 2007). E. spjeldnaesii has the same FAD in the Biskopås Conglomerate (Vidal, 1990; Fig. 6B) and the LAD, inferred from its synonymous species Echinosphaeridium maximum, is in the upper Doushatuo Formation (Yin, 1987; Vidal, 1990; Zhang et al., 1998; Yin et al., 2007). Even if not accepting the above synonymy, three other species of Ericiasphaera (marked as E. spp., in Fig. 3) co-occur in the upper Doushatuo Formation (Yin et al., 2007) suggesting that the evolutionary lineage of the genus survived the Marinoan glaciation.

Finally, in the view of the global record of survival, the claim that photosynthesis almost entirely collapsed during the glaciations, using $\partial^{13} \mathrm{C}$ interpretation over fossil evidence for photosynthetic biota, could not be sustained. The assumption that these biota could survive in a restricted refugium is also invalid because the environments needed to maintain nearly half of the preceding biota throughout the ice ages needed no doubt to be quite extensive. In this context, the critical discussion by Corsetti et al. $(2003,2006)$ about the fossil records, environments and their extent during the time is very pertinent. In these contributions, however, the conclusions that marine microbiota overcame the period of climatic perturbations almost in their pre-glacial diversity is exaggerated. The evaluation of the palaeontological record and survival rate by Corsetti et al. $(2003,2006)$ is treated with a reservation because the data seem incomplete and the value of a few microfossils from the interglacial deposits is overstated. Their review could be instead interpreted to indicate that some microbiota indeed survived (as the previous data and their new record support, and as is additionally documented here), and that although extinction evidently occurred in the Cryogenian it was not necessarily a mass extinction.

Butterfield (2007) postulated similar view on the evolution of biosphere of the time. In this contribution, the method of selecting the data and interpreting is beyond the scope of the present discussion because of the conflicting basic assumptions on which it is developed. These are to such a degree as assuming the Cryogenian to be a time of "monotonous physical environments" for life on Earth, and the disparity curve derived from acritarch data to be almost flat in an interval of 1600-630 Ma and taken as "profound evolutionary stasis". The Ediacaran/Cambrian boundary is depicted at ca. $530 \mathrm{Ma}$ (an estimation of the base of the Tommotian regional stage) and some $12 \mathrm{Ma}$ later than the recognized and IUGS-ratified age of the beginning of the Cambrian.

Remarkable to the discussion on the record of surviving biota is the report based on biomarker and sedimentological studies which reveals that marine primary productivity was substantial and that life indeed continued to flourish in a complex ecosystem during a low latitude glaciation at ca. $740-700 \mathrm{Ma}$ (Olcott et al., 2005). The biomarkers extracted from syn-glacial, organic-rich shale formation in Brazil, and being indigenous to the host rock, are specific to cyanobacteria, green sulfur bacteria and aerobic eukaryotes that may represent algae (Olcott et al., 2005). Cyanobacteria are evidently photosynthetic and inhabited the photic zone, whereas detected green sulfur bacteria occupied the anoxic, sulfidic photic zone. The abundance and high variety of biomarkers corresponding to both aerobic and anaerobic photoautotrophs and heterotrophs imply a diverse microbial community of bacteria, protoctists and perhaps other eukaryotes. The formation containing biomarkers accumulated in an ice-free environment, yet similar complex ecosystems could thrive within or beneath relatively thin sea ice from comparison to modern analogues around ice margin of Antarctica (Priscu et al., 1998; Mueller et al., 2001; Thomas and Dieckmann, 2002; Vincent et al., 2004). These kinds of conditions have been thought to reflect those existing during the Snowball Earth (Vincent et al., 2000, 2004), but comparisons must be taken with a caution following new observations in Antarctica (Wingham et al., 2006; see above). Compelling analogues with respect to marine ecosystems, comprising prokaryotes and eukaryotes, exist between modern polar regions and those inferred for Neoproterozoic (although not taxonomically), yet as pointed by Olcott et al. (2005), there is not yet evidence to deduce whether their studied site was a solitary refugium or a more globally representative place at the time. Consequently, if the margin of the São Francisco Craton upon which the formation was deposited has not been an isolated basin, this would provide a strong argument against the hypothesis of global sea ice cover and impoverished ecosystem in the Neoproterozoic. The biomarkers alone, indicative of the existence of a diverse biota including photosynthetic bacteria and eukaryotes during the glaciation at ca. $740-700 \mathrm{Ma}$ in a low latitude pericratonic basin, advocate a less extreme version of Neoproterozoic climate than is represented by the Snowball Earth Hypothesis.

\section{Early metazoans}

Compilation of the fossil record and molecular clock dates links the origins of some metazoan clades to the time preceding at least the two younger of the Neoproterozoic glacial intervals: the Marinoan at ca. $635 \mathrm{Ma}$ and Gaskiers at ca. $580 \mathrm{Ma}$ (Peterson and Butterfield, 2005). The interglacial radiations of metazoans, known to be sponges and cnidarians, could have been stimulated by increased oxygen concentration in seawater associated with a cold climate due to the greater oxygen solubility in cold water, content of certain elements and minerals, and salinity for metazoan metabolism and biomineralization (Fedonkin, 1996, 2003). The oxygenation of the Earth's oceans during the Cryogenian and in particular during the Ediacaran (Fike et al., 2006) period, is thought to be directly related to the appearance of the first Ediacara-type metazoans. The lowest occurrence of some Ediacaran-type species is related to increased oxygen content in the hydro- and atmosphere (Canfield et al., 2007).

Significantly, the isolated equatorial land masses at some distance from the main continent, i.e. islands, predicted to exist in the model by Hyde et al. (2000), could have provided just the conditions needed for vicariance biogeography that might have propagated allopatric speciation of early metazoans. The speciation due to a vicariance biogeography operates by isolation and subsequent divergence (leading to rise of new species) of an initial population into restricted populations by geographic/environmental changes in a prolonged time interval. The ecological barriers formed by ice sheets and frozen seaways must have split natural populations and obstructed their dispersal causing not only a reduction in population numbers and/or extinction but perhaps also speciation in some refugia. The earliest known metazoans were probably benthic (Hofmann et al., 1990; Canfield et al., 2007) and therefore more prone to environmental pressure due to glaciations. Evidently a few metazoans survived at least the last glacial intervals (Hofmann et 
al., 1990; Xiao et al., 1998; Peterson and Butterfield, 2005; Canfield et al., 2007). Accepting alternative molecular clocks timing the early origins of metazoans, they might have been around before the Cryogenian (Doolittle et al., 1996; Fedonkin, 1996; McNamara, 1996; Wray et al., 1996; Wang et al., 1999; Runnegar, 2000; Blair and Hedges, 2004; Douzery et al., 2004; Hedges et al., 2004; Pisani et al., 2004; Yoon et al., 2004; Peterson and Butterfield, 2005). It is considered that a substantial population in the benthic realm persisted through the Cryogenian interval to provide a critical genetic stock enabling the rapid radiations in the post-glacial Ediacaran Period, which are elegantly documented in the fossil record. Marine benthic environments must then have been preserved also throughout the Cryogenian times.

\section{Conclusions}

It is apparent from the global fossil record that the geologic time span of numerous eukaryotic species and entire prokaryotic microbial communities, existing in planktic and benthic marine habitats, embraces the Cryogenian glacial intervals.

The environmental conditions of the biota, constrained by their well-recognized metabolic processes (nutrition, respiration, reproduction) and mode of life, must have been sustained and sufficiently robust throughout the Cryogenian Period.

To support photoautotrophic, aerobic and sexually reproducing eukaryotes, although planktic but having complex life cycle with alternating generations periodically resting in the sediment, and also photoautotrophic, aerobic but benthic prokaryotes, as the biota were, the habitats of oxygenated, marine basins with photic zone and access to the substrate must have been functioning. To supply and replenish mineral nutrients and oxygen content, the hydrologic cycle had to be active.

An Earth System model with open marine realm, active hydrologic cycle and free access to the seafloor is required for the Cryogenian Period. From a perspective of the biosphere, the radical version of the Snowball Earth Hypothesis is invalid, and the Slushball Earth model or similar is more adequate.

\section{Acknowledgements}

I acknowledge funding by the Swedish Research Council (Vetenskapsrådet) through research grant no. 621-2004-5316. I appreciated and enjoyed discussions on the Proterozoic microbiota with Kath Grey, Shuhai Xiao, and Yin Leiming. However, the opinions expressed here are of my own responsibility. Gary Wife, Evolutionary Biology Centre, Uppsala University, is acknowledged for his excellent image processing.

This study benefited from the inspiring presentations and lively debates with many colleagues during the Snowball Earth 2006 Conference at Monte Verità, Ticino, Switzerland. The organizers, James L. Etienne and Philip Allen, created exceptional atmosphere during the meeting, including the thunderstorms. I especially thank Graham Shields for his comments and thorough reading of the early draft of the manuscript, and the Referees for their specific suggestions, which improved the manuscript. I acknowledge discussions with colleagues working in the IGCP project 512.

\section{References}

Allen, P.A., 2006a. Snowball Earth on trial. Eos Transactions American Geophysical Union 87 (45), 495.

Allen, P.A., 2006b. Snowball Summit on Mountain of Truth. Geoscientist 16, 14-19.

Allen, P.A., Leather, J., Brasier, M.D., 2004. The Neoproterozoic Fiq glaciation and its aftermath, Huqf supergroup of Oman. Basin Research 16, 507-534.

Arouri, K., Greenwood, P.F., Walter, M.R., 2000. Biological affinities of Neoproterozoic acritarchs from Australia: microscopic and chemical characterisation. Organic Geochemistry 31, 75-89.
Bell, R.E., Studinger, M., Shuman, C.A., Fahnestock, M.A., Joughin, I., 2007. Large subglacial lakes in East Antarctica at the onset of fast-flowing ice streams. Nature 445, 904-907.

Bell, R.E., Studinger, M., Tikku, A.A., Clarke, G.K.C., Gutner, M.M., Meertens, C., 2002. Origin and fate of Lake Vostok water refrozen to the base of the East Antarctic ice sheet. Nature 416, 307-310.

Bingen, B., Griffin, W.L., Torsvik, T.H., Saeed, A., 2005. Timing of Late Neoproterozoic glaciation on Baltica constrained by detrital zircon geochronology in the Hedmark Group, south-east Norway. Terra Nova 17, 250-258.

Blair, J.E., Hedges, S.B., 2004. Molecular clocks do not support the Cambrian explosion. Molecular Biology and Evolution 22, 387-390.

Bowring, S.A., Condon, D., 2006. Sequencing the Neoproterozoic: the importance of high-precision geochronology. Snowball Earth 2006 Conference, July 16-21, Monte Verità, Ticino, Switzerland, Abstracts, 21-22.

Butterfield, N.J., 2000. Bangiomorpha pubescens n.gen.: implications for the evolution of sex, multicellularity and the Mesoproterozoic-Neoproterozoic radiation of eukaryotes. Paleobiology 26, 386-404.

Butterfield, N.J., 2005a. Probable Proterozoic fungi. Paleobiology 31, 165-182.

Butterfield, N.J., 2005b. Reconstructing a complex early Neoproterozoic eukaryote, Wynniatt Formation, arctic Canada. Lethaia 38, 155-169.

Butterfield, N.J., 2007. Macroevolution and macroecology through deep time. Palaeontology 50, 41-55.

Butterfield, N.J., Knoll, A.H., Swett, K., 1994. Paleobiology of the Neoproterozoic Svanbergfjellet Formation, Spitsbergen. Fossils and Strata 34, 84 pp.

Canfield, D.E., 1998. A new model for Proterozoic ocean chemistry. Nature 396, 450-453.

Canfield, D.E., Poulton, S.W., Narbonne, G.M., 2007. Late-Neoproterozoic deep-ocean oxygenation and the rise of animal life. Science 315, 92-95.

Chandler, M.A., Sohl, L.E., 2000. Climate forcings and the initiation of low-latitude ice sheets during the Neoproterozoic Varanger glacial interval. Journal of Geophysical Research 105, 20737-20756.

Cloud, P., 1988. Oasis in Space. Earth History from the Beginning. W.W. Norton \& Company, New York/London, 508 pp.

Colbath, G.K., Grenfell, H.R., 1995. Review of biological affinities of Paleozoic acid resistant, organic-walled eukaryotic algal microfossils (including "acritarchs"). Review of Palaeobotany and Palynology 86, 287-314.

Compston, W., Sambridge, M.S., Reinfrank, R.F., Moczydłowska, M., Vidal, G., Claesson, S., 1995. Numerical ages of volcanic rocks and the earliest faunal zone within the Late Precambrian of east Poland, Journal of the Geological Society. London 152, 599-611.

Condon, D.J., Prave, A.R., 2000. Two from Donegal: Neoproterozoic glacial episodes on the northeast margin of Laurentia. Geology 28, 951-954.

Condon, D.J., Prave, A.R., Benn, D.I., 2002. Neoproterozoic glacial-rainout intervals: observations and implications. Geology 30, 35-38.

Corsetti, F.A., Awramik, S.M., Pierce, D., 2003. A complex microbiota from Snowball Earth times: microfossils from the Neoproterozoic Kingston Peak Formation, Death Valley, USA. Proceedings of the National Academy of Sciences of the United States of America 100, 4399-4404.

Corsetti, F.A., Olcott, A.N., Bakermans, C., 2006. The biotic response to Neoproterozoic Snowball Earth. Palaeogeography, Palaeoclimatology, Palaeoecology 232, 114-130.

Crowley, T.J., Hyde, W.T., Peltier, W.R., 2001. $\mathrm{CO}_{2}$ levels required for deglaciation of a “near-snowball” Earth. Geophysical Research Letters 28, 283-286.

Doolittle, R.F., Feng, D.F., Tsang, S., Cho, G., Little, E., 1996. Determining divergence times of the major kingdoms of living organisms with a protein clock. Science 271, 470-477.

Douzery, E.J.P., Snell, E.A., Bapteste, E., Delsuc, F., Philippe, H., 2004. The timing of eukaryotic evolution: does a relaxed molecular clock reconcile proterins and fosslis? Proceedings of the National Academy of Sciences of the United States of America 101, 15386-15391.

Etienne, J.L., Allen, P.A., Rieu, R., Le Guerroué, E., 2007. Neoproterozoic glaciated basins: a critical review of the Snowball Earth Hypothesis by comparison with Phanerozoic glaciations. In: Hambrey, MJ., Christofferson, P., Glasser, N.F., Hubbard, B. (Eds.), Glacial Sedimentary Processes and Products, 39. International Association of Sedimentologists Special Publication, pp. 343-399.

Evens, D.A.D., 2006. Proterozoic low orbital obliquity and axial-dipolar geomagnetic field from evaporite palaeolatitudes. Nature 444, 51-55.

Eyles, N., 2006. A sedimentological test of Snowball Earth: Namibia revised. In: Snowball Earth 2006 Conference, Monte Verità, Ticino, Switzerland, July 16-21, pp. 36-37 (Abstracts).

Eyles, N., 2008. Glacio-epochs and the supercontinent cycle after $\sim 3.0 \mathrm{Ga:}$ tectonic boundary conditions for glaciation. Palaeogeography, Palaeoclimatology, Palaeoecology 258, 89-129.

Eyles, N., Januszczak, N., 2004. Zipper-rift": a tectonic model for Neoproterozoic glaciations during the breakup of Rodinia after 750 Ma. Earth Science Reviews $65,1-73$.

Eyles, N., Januszczak, N., 2007. Syntectonic subaqueous mass flows of the Neoproterozoic Otavi Group, Namibia: where is the evidence of global glaciation. Basin Research 19, 179-198

Fairchild, I.J., Kennedy, M.J., 2007. Neoproterozoic glaciation in the Earth System. Journal of the Geological Society, London 164, 895-921.

Fedonkin, M.A., 1996. Cold-water cradle of animal life. Paleontologicheskii Zhurnal (English version) 30, 669-673.

Fedonkin, M.A., 2003. The origin of the Metazoa in the light of the Proterozoic fossil record. Paleontological Research 7, 9-41. 
Fedonkin, M.A., Waggoner, B.M., 1997. The Late Precambrian fossil Kimberella is a mollusc-like bilaterian organism. Nature $388,868-871$.

Fike, D.A., Grotzinger,J.P., Pratt, L.M., Summons, R.E., 2006. Oxidation of the Ediacaran Ocean. Nature 444, 744-747.

Gehling, J.G., 1999. Microbial mats in terminal Proterozoic siliciclastics: Ediacaran death masks. Palaios 14, 40-57.

Golubic, S., Hofmann, H.J., 1976. Comparison of Holocene and mid-Precambrian Entophysalidacea (Cyanophyta) in stromatolitic algal mats: cell division and degradation. Journal of Paleontology 50, 1074-1082.

Gradstein, F., Ogg, J., Smith, A. (Eds.), 2004. A Geologic Time Scale 2004. Cambridge University Press, 598 pp.

Greene, C.H., Pershing, A.J., 2007. Climate drives sea change. Science 315, 1084-1085.

Grey, K., 2005. Ediacaran palynology of Australia. Memoir of the Association of Aus tralasian Palaeontologists 31, 1-439.

Grey, K., Corkeron, M., 1998. Late Neoproterozoic strmatolites in glacigenic successions of the Kimberley region, Western Australia: evidence for a younger Marinoan glaciation. Precambrian Research 92, 65-87.

Grey, K., Walter, M.R., Calver, C.R., 2003. Neoproterozoic biotic divesification: Snowball Earth or aftermath of the Acraman impact? Geology 31, 459-462.

Halverson, G.P., 2006. A Neoproterozoic chronology. In: Xiao, S., Kaufman, A.J. (Eds.) Neoproterozoic Geobiology and Paleobiology. Springer, pp. 231-271.

Harland, W.B., 1964. Evidence of Late Precambrian glaciation and its significance. In: Nairn, A.E.M. (Ed.), Problems in Palaeoclimatology. Interscience/John Wiley \& Sons, London, pp. 119-149, 180-184.

Harland, W.B., 2007. Origins and assessment of Snowball Earth Hypotheses. Geological Magazine 144 (4), 633-642.

Hedges, S.B., Blair, J.E., Venturi, M.L., Shoe, J.L., 2004. A molecular timescale of eukaryote evolution and the rise of complex multicellular life. BMC Evolutionary Biology 4 (2), doi:10.1186/1471-2148-4-2.

Hoffman, P.F., Kaufman, A.J., Halverson, G.P., Schrag, D.P., 1998. A Neoproterozoic Snowball Earth. Science 281, 1342-1346.

Hoffman, P.F., Schrag, D.P., 2000. Snowball Earth. Scientific American 282, 62-75.

Hoffman, P.F., Schrag, D.P., 2002. The Snowball Earth Hypothesis: testing the limits of global change. Terra Nova 14, 129-155.

Hofmann, H.J., 1976. Precambrian microflora, Belcher Islands, Canada: significance and systematics. Journal of Paleontology 50, 1040-1073.

Hofmann, H.J., Aitken, J.D., 1979. Precambrian biota from the Little Dal Group Mackenzie Mountains, northwestern Canada. Canadian Journal of Earth Science $16,150-166$.

Hofmann, H.J., Narbonne, G.M., Aitken, J.D., 1990. Ediacaran remains from intertillite beds in northwestern Canada. Geology 18, 1199-1202.

Hyde, W.T., Crowley, T.J., Baum, S.K., Peltier, W.R., 2000. Neoproterozoic "snowball Earth" simulations with a coupled climate/ice-sheet model. Nature 405 , 425-429.

Jankauskas, T.V., et al. (Eds.), 1989. Mikrofossili dokembriya SSSR (Precambrian microfossils of the USSR). Nauka, Leningrad, 190 pp. (in Russian).

Javaux, E.J., Knoll, A.H., Walter, M., 2003. Recognizing and Interpreting the Fossils of Early Eukaryotes. Origins of Life and Evolution of the Biosphere, 33. Kluwer Academic Publishers, Netherlands, pp. 75-94.

Javaux, E.J., Knoll, A.H., Walter, M., 2004. TEM evidence for eukaryotic diversity in mid-Proterozoic oceans. Geobiology 2, 121-132.

Jiang, G., Kennedy, M.J., Christie-Blick, N., 2003. Stable isotopic evidence for methane seeps in Neoproterozoic postglacial cap carbonates. Nature 426, 822-826.

Kapitsa, A., Ridley, J.K., Robin, G., de, Q., Siegert, M.J., Zotikov, I., 1996. Large deep freshwater lake beneath the ice of central East Antarctica. Nature 381, 684-686.

Kennedy, M.J., Runnegar, B., Prave, A.R., Hoffman, K.-H., Arthur, M.A., 1998. Two or four Neoproterozoic glaciations? Geology 26, 1059-1063.

Kennedy, M.J., Christie-Blick, N., Prave, A.R., 2001a. Carbon isotopic composition of Neoproterozoic glacial carbonates as a test of paleoceanographic models for Snowball Earth phenomena. Geology 29, 1135-1138.

Kennedy, M.J., Christie-Blick, N., Sohl, L.E., 2001b. Are Proterozoic cap carbonates and isotopic excursions a record of gas hydrate destabilization following Earth's coldest intervals? Geology 29, 443-446.

Kerr, R.A., 2000. An appealing snowball earth that's still hard to swallow. Science $287,1734-1736$

Kirschvink, J.L., 1992. Late Proterozoic Low-Latitude Global Glaciation: the Snowball Earth. In: Schopf, J.W., Klein, C. (Eds.), The Proterozoic Biosphere: A Multidisciplinary Study. Cambridge University Press, pp. 51-52.

Kirschvink, J.L., Gaidos, E.J., Bertani, L.E., Beukes, N.J., Gutzmer, J., Maepa, L.N., Steinberger, R.E., 2000. Palaeoproterozoic Snowball Earth: extreme climatic and geochemical global change and its biological consequences. Proceedings of the National Academy of Sciences of the United States of America 97, 1400-1405.

Knoll, A.H., 1982. Microfossils from the late Precambrian Draken Conglomerate, Ny Friensland, Svalbard. Journal of Paleontology 56, 755-790.

Knoll, A.H., 1994. Proterozoic and Early Cambrian protists: Evidence for accelerating evolutionary tempo. Proceedings of the National Academy of Sciences of the United States of America 91, 6743-6750.

Knoll, A.H., 1996. Archean and Proterozoic paleontology. In: Jansonius, J., McGregor, D.C. (Eds.), Palynology: Principles and Applications. American Association of Stratigraphic Palynologists Foundation, Salt Lake City, Utah, pp. 51-80.

Knoll, A.H., 2003. Life on a Young Planet. Princeton University Press, Princeton and Oxford, $277 \mathrm{pp}$.

Knoll, A.H., Swett, K., Mark, J., 1991. Paleobiology of a Neoproterozoic tidal flat/lagoonal complex: the Draken Conglomerate Formation, Spitsbergen. Journal of Paleontology 65, 531-570.
Knoll, A.H. Javaux, E.J. Hewitt, D., Cohen, P. 2006. Eukaryotic organisms in Proterozoic oceans. Philosophical Transactions of the Royal Society, B 361 , 1023-1038

Lewis, A.R., Marchant, D.R., Kowalewski, D.E., Baldwin, S.L., Webb, L.E., 2006. The age and origin of the Labyrinth, western Dry Valleys, Antarctica: evidence for extensive middle Miocene subglacial floods and freshwater discharge to the Southern Ocean. Geology 34, 513-516.

Martin, F., 1993. Acritarchs: a review. Biological Review 68, 475-538.

Martiny, J.B., Bohannan, B.J.M., Brown, J.H., et al., 2006. Microbial biogeography: putting microorganisms on the map. Nature Reviews Microbiology 4, 102-112.

McKay, C.P., Hand, K.P., Doran, P.T., Andersen, D.T., Priscu, J.C., 2003. Clathrate formation and the fate of noble and biologically useful gases in Lake Vostok, Antarctica. Geophysical Research Letters 30.

McNamara, K.J., 1996. Dating the origin of animals. Science 274, 1995-1996.

von Mering, C., von Hugenholtz, P., Raes, J., Tringe, S.G., Doerks, T., Jensen, L.J., Ward, N. Bork, P. 2007. Quantitative phylogenetic assessment of microbial communities in diverse environments. Science 315, 1126-1130.

Moczydłowska, M., 1991. Acritarch biostratigraphy of the Lower Cambrian and the Precambrian-Cambrian boundary in southeastern Poland. Fossils and Strata 29 $127 \mathrm{pp}$.

Moczydłowska, M., 2002. Early Cambrian phytoplankton diversification and appearance of trilobites in the Swedish Caledonides with implications for coupled evolutionary events between primary producers and consumers. Lethaia 35 191-214.

Moczydłowska, M., 2004. Neoproterozoic microbiota-adaptations and survival of severe environmental disturbances. In: Proceedings of the 11th International Palynological Congress, vol. 14, Granada, Spain, Polen, July 4-9, p. 129.

Moczydłowska, M., 2005. Taxonomic review of some Ediacaran acritarchs from the Siberian Platform. Precambrian Research 136, 283-307.

Moczydłowska, M., 2006. The Ediacaran phytoplankton and cyanobacteria-a recovery after Snowball Earth conditions. In: Snowball Earth 2006 Conference, Monte Verità, Ticino, Switzerland, July 16-21, p. 76 (Abstracts).

Moczydłowska, M., 2008. New records of late Ediacaran microbiota from Poland. Precambrian Research 167, 71-92.

Mueller, D.R., Vincent, W.F., Pollard, W.H., Fritsen, C.H., 2001. Glacial cryoconite ecosystems: a bipolar comparison of algal communities and habitats. Nova Hedwigia, Beiheft 123, 173.

Olcott, A.N., Sessions, A.L., Corsetti, F.A., Kaufman, A.J., Flavio de Oliviera, T., 2005. Biomarker evidence for photosynthesis during Neoproterozoic glaciation Sciencexpress/www.sciencexpress.org/29 September 2005/Page 1/10.1126/science.1115769.

Paczesna, J., Krzeminska, E., Moczydłowska-Vidal, M., 2008. Profil litologicznostratygraficzny według rdzeni i pomiarów geofizycznych. Ediakar. In: Paczesna, J. (Ed.), Łopiennik IG 1. Profile Glebokich Otworów Wiertniczych Panstwowego Instytutu Geologicznego, vol. 123, pp. 58-62.

Peltier, W.R., Crowley, J.W., 2006. A climate coupled carbon cycle model of the Neoproterozoic. In: Snowball Earth 2006 Conference, Monte Verità, Ticino, Switzerland, July 16-21, pp. 83-84 (Abstracts).

Peltier, W.R., Tarasov, L., Vettoretti, G., Solheim, L., 2004. Climate dynamics in deep time: modelling the "snowball bifurcation" and assessing the plausibility of its occurrence. In: Jenkins, G., McMenamin, M., Sohl, L., McKay, C. (Eds.), The Extreme Proterozoic: Geology, Geochemistry, and Climate. American Geophysical Union, Geophysical Monograph Series 146, 107-124.

Peterson, K.J., Butterfield, N.J., 2005. Origin of the Eumetazoa: testing ecologica predictions of molecular clocks against the Proterozoic fossil record. Proceedings of the National Academy of Sciences of the United States of America 102 9547-9552.

Pisani, D., Poling, L.L., Lyons-Weiler, M., Hedges, S.B., 2004. BMC Evolutionary Biology 2,1-10.

Pollard, D., Kasting, J.F., 2005. Snowball Earth: a thin-ice solution with flowing sea glaciers. Journal of Geophysical Research-Atmospheres 110, C07010, doi:10.1029/2004JC002525.

Poulsen, C.J., 2003. Absence of a runaway ice-albedo feedback in the Neoproterozoic. Geology 31, 473-476.

Poulsen, C.J., Pierrehumbert, R.T., Jacob, R.L., 2001. Impact of ocean dynamics on the simulation of the Neoproterozoic "snowball Earth". Geophysical Research Letters 28, 1575-1578.

Powell, C.McA., Pisarevsky, S.A., 2002. Late Neoproterozoic assembly of East Gondwana. Geology 30, 3-6.

Powell, C.McA., Li, Z.X., McElhinny, M.W., Meert, J.G., Park, J.K., 1993. Paleomagnetic constraints on timing of the Neoproterozoic breakup of Rodinia and the Cambrian formation of Gondwana. Geology 21, 889-892.

Prave, A.R., 1999a. Two diamictites, two cap carbonates, two $\partial^{13} \mathrm{C}$ excursions, two rifts: the Neoproterozoic Kingstone Peak Formation, Death Valley, California. Geology 27, 339-342.

Prave, A.R., 1999b. The Neoproterozoic Dalradian Supergroup of Scotland: an alternative hypothesis. Geological Magazine 136, 609-617.

Priscu, J.C., Fritsen, C.H., Adams, E.E., Giovannoni, S.J., Paerl, H.W., McKay, C.P., Doran, P.T., Gordon, D.A., Lanoil, B.D., Pinckney, J.L., 1998. Perennial Antarctic Lake Ice: an Oasis for Life in a Polar Desert. Science 280, 2095

Runnegar, B., 2000. Loophole for Snowball Earth. Nature 405, 403-404.

Schopf, J.W., 1968. Microflora of the Bitter Springs Formation, Late Precambrian, Central Australia. Journal of Paleontology 42, 651-688.

Schopf, J.W., 1999. Cradle of Life. Princeton University Press, Princeton, New Jersey, $367 \mathrm{pp}$ 
Schopf, J.W., Klein, C. (Eds.), 1992. The Proterozoic Biosphere: A Multidisciplinary Study. Cambridge University Press, 1338 pp.

Seong-Joo, L., Golubic, S., 1998. Multi-trichomous cyanobacterial microfossis from the Mesoproterozoic Gaoyuzhung Formation, China: Paleoecological and taxonomic implications. Lethaia 31, 169-184.

Sepkoski Jr. J.J., Schopf, J.W., 1992. Biotic diversity and rates of evolution during Proterozoic and earliest Phanerozoic time. In: Schopf, J.W., Klein, C. (Eds.), The Proterozoic Biosphere: A Multidisciplinary Study. Cambridge University Press, pp. 521-566.

Sergeev, V.N., 2006. Okremnennye mikrofossili dokembriya: priroda, klassifikatsiya i biostratigraphitcheskoe znatchenie (Precambrian Microfossils in Cherts: their Paleobiology, Classification and Biostratigraphic Usefulness). GEOS, Moscow, 280 pp. (in Russian).

Shields, G., 2006. The Snowball Earth Hypothesis is Dead. Long Live the Snowball Earth! IAS.

Talyzina, N.M., Moczydłowska, M., 2000. Morphology and ultrastructural studies of some acritarchs from the Lower Cambrian Lükati Formation, Estonia. Review of Palaeobotany and Palynology 112, 1-21.

Tappan, H., 1980. The Paleobiology of Plant Protists. W.H. Freeman, San Fransisco, $1028 \mathrm{pp}$.

Thomas, D.N., Dieckmann, G.S., 2002. Antarctic sea-ice-a habitat for extremophiles. Science 295, 641-644.

Timofeev, B.V., 1973. Mikrofitofossili dokembriya Ukrainy (Precambrian Microphytofossils in Ukraine). Nauka, Leningrad, 58 pp. (in Russian).

Traverse, A., 2007. Paleopalynology. Springer, Dordrecht, 813 pp.

Veis, A.F., Vorobeva, N.G., Golubkova, E.Yu., 2006. The early Vendian microfossils first found in the Russian Plate: taxonomic composition and biostratigraphic significance. Stratigraphy and Geological Correlation 14 (4) 368-385. Nauka/Interperiodica, Moscow (Original Russian Text: Veis, A.F., Vorob'eva, N.G., Golubkova, E.Yu., 2006. Published in Stratigrafiya. Geologicheskaya Korrelyatsiya 14 (4) 28-46).

Vidal, G., 1981. Micropalaeontology and biostratigraphy of the Upper Proterozoic and Lower Cambrian sequence in East Finnmark, Northern Norway. Norges geologiske undersokelse $362,53 \mathrm{pp}$.

Vidal, G., 1990. Giant acanthomorph acritarchs from the Upper Proterozoic in southern Norway. Palaeontology 33, 287-298.

Vidal, G., 1994. Early ecosystems: limitations imposed by the fossil record. In: Bengtson, S. (Ed.), Early Life on Earth, Nobel Symposium No. 84, Columbia University Press, New York, pp. 298-311.

Vidal, G., Ford, T., 1985. Microbiotas from the late Proterozoic Chuar Group (northern Arizona) and Uinta Mountain Group (Utah) and their chronostratigraphic implications. Precambrian Research 28, 349-489.

Vidal, G., Knoll, A.H., 1982. Radiations and extinctions of phytoplankton in the late Proterozoic and early Cambrian. Nature 297, 57-60.

Vidal, G., Moczydłowska, M., 1995. The Neoproterozoic of Baltica-stratigraphy, palaeobiology and general geological evolution. Precambrian Research 73 , 197-216.

Vidal, G., Moczydłowska, M., 1997. Biodiversity, speciation and extinction trends of Proterozoic and Cambrian phytoplankton. Paleobiology 23, 230-246.
Vidal, G. Moczydłowska, M., Rudavskaya, V.A., 1993. Biostratigraphical implications of a Chuaria-Tawuia assemblage and associated acritarchs from the Neoproterozoic of Yakutia. Palaeontology 36, 387-402.

Vincent, W.F., Howard-Williams, C., 2000. Life on Snowball Earth. Science 287, 2421.

Vincent, W.F., Gibson, J.A.E., Pienitz, R., Villeneuve, V., 2000. Naturwissenschaften 87, 137-141.

Vincent, W.F., Mueller, D.R., Bonilla, S., 2004. Ecosystems on ice: the microbial ecology of Markham Ice Shelf in the high Arctic. Cryobiology 48, 103-112.

Walter, M.R., Veevers, J.J., Calver, C.R., Gorjan, P., Hill, A.C., 2000. Dating the 840-544 Ma Neoproterozoic interval by isotopes of strontium, carbon, and sulfur in seawater, and some interpretive models. Precambrian Research 100,371-433.

Wang, D.Y.-C., Kumar, S., Hedges, S.B., 1999. Proceedings of the Royal Society, London, B 266, 163-171.

Warren, S.G., Brandt, R.E., Grenfell, T.C., McKay, C.P., 2002. Snowball Earth: ice thickness on the tropical ocean. Journal of Geophysical Research-Oceans 107 (C10), 3167, doi:10-1029/2001JC001123.

Williams, G.E., 1975. Late Precambrian glacial climate and the Earth's obliquity. Geological Magazine 112, 441-444.

Williams, G.E., 1993. History of the Earth's obliquity. Earth Science Reviews 34, 1-45.

Williams, G.E., Kasting, J.F., Frakes, L.A., 1998. Low-latitude glaciation and rapid changes in the Earth's obliquity explained by obliquity-oblateness feedback. Nature 396, 453-455.

Willman, S., Moczydłowska, M., 2008. Ediacaran acritarch biota from the Giles 1 drillhole, Officer Basin, Australia, and its potential for biostratigraphic correlation. Precambrian Research 162, 498-530.

Wingham, D.J., Siegert, M.J., Shepherd, A., Muir, A.S., 2006. Rapid discharge connects Antarctic subglacial lakes. Nature 440, 1033-1036.

Wray, G.A., Levontin, J.S., Schapiro, L.H., 1996. Molecular evidence for deep Precambrian divergences among metazoan phyla. Science 274, 568-573.

Xiao, S., 2004. Neoproterozoic glaciations and the fossil record. In: Jenkins, G., McMenamin, M., Sohl, L., McKay, C. (Eds.), The Extreme Proterozoic: Geology, Geochemistry, and Climate. American Geophysical Union, Geophysical Monograph Series 146, 199-214.

Xiao, S., Dong, L., 2006. On the morphological and ecological history of Proterozoic macroalgae. In: Xiao, S., Kaufman, A.J. (Eds.), Neoproterozoic Geobiology and Paleobiology. Springer, pp. 57-90.

Xiao, S., Zhang, Y., Knoll, A.H., 1998. Three-dimensional preservation of algae and animal embryos in a Neoproterozoic phosphorite. Nature 391, 553-558.

Yin, L., 1987. Microbiotas of latest Precambrian sequences in China. In: Nanjing Institute of Geology and Palaeontology (Ed.), Stratigraphy and Palaeontology of Systemic Boundaries in China, Precambrian-Cambrian Boundary, vol. 1, Nanjing University Publishing House, Nanjing, pp. 415-494.

Yin, L., Zhu, M., Knoll, A.H., Yuan, X., Zhang, J., Hu, J., 2007. Nature 446, 661-663.

Yoon, H.S. Hackett, J.D., Ciniglia, C. Pinto, G. Bhattacharya, D. 2004. A molecular timeline for the origin of photosynthetic eukaryotes. Molecular Biology and Evolution 21, 809-818.

Zhang, Y., Yin, L., Xiao, S., Knoll, A.H., 1998. Permineralized fossils from the terminal Proterozoic Doushantuo Formation, South China. Journal of Paleontology Memoir 50, 52. 